\title{
Lsc $\beta$ and lsc $\gamma$, two novel levansucrases of Pseudomonas syringae pv. actinidiae biovar 3, the causal agent of bacterial canker of kiwifruit, show different enzymatic properties
}

\author{
Simone Luti ${ }^{\text {a,* }}$, Sara Campigli ${ }^{\text {b }}$, Francesco Ranaldi ${ }^{\text {a }}$, Paolo Paoli ${ }^{\text {a }}$, Luigia Pazzagli a ${ }^{\text {, Guido Marchi }}{ }^{\text {b }}$ \\ a Department of Experimental and Clinical Biomedical Sciences, University of Florence, Italy \\ ${ }^{\mathrm{b}}$ Department of Agriculture, Food, Environment and Forestry, University of Florence, Italy
}

\section{A R T I C L E I N F O}

\section{Article history:}

Received 11 January 2021

Received in revised form 21 February 2021

Accepted 25 February 2021

Available online 03 March 2021

\section{Keywords:}

Levansucrase

Levan

Pseudomonas syringae

Plant pathogen

Sucrose

Actinidia spp.

\begin{abstract}
A B S T R A C T
Bacterial canker disease caused by Pseudomonas syringae pv. actinidiae (Psa) biovar 3 involved all global interest since 2008. We have found that in Psa3 genome, similarly to other P. syringae, there are three putative genes, Isc $\alpha$, $l s c \beta$ and $l s c \gamma$, coding for levansucrases. These enzymes, breaking the sucrose moiety and releasing glucose can synthetize the fructose polymer levan, a hexopolysaccharide that is well known to be part of the survival strategies of many different bacteria. Considering $l s c \alpha$ non-coding because of a premature stop codon, in the present work we cloned and expressed the two putatively functional levansucrases of Psa3, $\operatorname{lsc} \beta$ and lsc $\gamma$, in E. coli and characterized their biochemical properties such as optimum of $\mathrm{pH}$, temperature and ionic strength. Interestingly, we found completely different behaviour for both sucrose splitting activity and levan synthesis between the two proteins; lsc $\gamma$ polymerizes levan quickly at $\mathrm{pH} 5.0$ while $\mathrm{lsc} \beta$ has great sucrose hydrolysis activity at $\mathrm{pH}$ 7.0. Moreover, we demonstrated that at least in vitro conditions, they are differentially expressed suggesting two distinct roles in the physiology of the bacterium.
\end{abstract}

(c) 2021 Elsevier B.V. All rights reserved.

\section{Introduction}

Within the highly diverse group of Gram-negative bacteria known as the Pseudomonas syringae species complex (Pssc) [1], Pseudomonas syringae pv. actinidiae (Psa) is the causative agent of canker disease of kiwifruit, among which Actinidia chinensis var. deliciosa and A. chinensis var. chinensis are the major hosts (https://gd.eppo.int/ taxon/PSDMAK). Production of kiwifruit is increasing because of consumer demand for its good taste and nutrition, but outbreaks of this bacterial disease often result in sudden and severe economic losses and limitations in kiwifruit cultivation worldwide [2].

Based on genetic diversity and toxins production [2-4] Psa has been categorized into six biovars (biovars 1-6). However, recently biovar 4 has been transferred to another pathovar, actinidifoliorum (Pfm) [5]. Whole genome comparisons have clearly shown that biovar 1 (Psa1), biovar 2 (Psa2) and biovar 3 (Psa3) are genetically distinct lineages of the same source population, each responsible of an independent outbreak. Outbreaks caused by Psa1 and Psa2 have remained geographically limited to Japan and Korea, respectively, but the expansion of Psa3, that has started at the end of last decade possibly in Italy, has now reached kiwi orchards worldwide, leading to what is currently

\footnotetext{
* Corresponding author at: viale Morgagni 50, 50134 Florence, Italy.

E-mail address: simone.luti@unifi.it (S. Luti).
}

referred to as the bacterial canker pandemy [6,7]. Moreover the same type of comparisons have pointed out a differential distribution of genes putatively coding for pathogenicity and virulence factors, that could possibly account for the higher agressivity of Psa3 respect to biovars 1 and $2[7,8]$. More recently, studying gene expression of Psa3 during the late stages of kiwi plantlets infection or in response to exposure to antimicrobial compounds, it has been observed, among the rest, an increase of the expression of genes coding for the exopolysaccharide (EPS) alginate [9-11]. P. syringae produces two major EPSs: alginate and levan. However, meanwhile it is well documented that alginate contributes both to the epiphytic fitness and to virulence of $P$. syringae, much lesser is known about the functions of levan [12-15]. Levan is nonstructural EPS produced by many microbes including Archaea, fungi and a wide range of bacteria but only rarely by plants [16]. It is composed of fructose units connected predominantly by $\beta-(2-6)$ linkages with some $\beta-(2,1)$ branching points. In bacteria it is believed that levan constitutes a form of energy storage, or an important structural component of some bacterial biofilms, matrices that embed cells in vitro and in vivo, and which are composed also by proteins, lipids and nucleic acids thus playing a major role in the survival of bacteria [17]. Most interestingly however, this is not true for P. syringae, for which it has been proven that levan, as well as alginate, has only a marginal role in the architectural form of the biofilm [18]. Nevertheless levan it might be particularly important during early stages of infection 
by masking and protecting the pathogen from the detection and defence mechanisms of the host, as it has been proposed to be the case for P. syringae pv. phaseolicola [19]. Moreover, some observations using a levan deficient mutant of $P$. syringae pv. glycinea PG4180, have suggested a decrease in the epiphytic survival, multiplication and symptoms induction when the mutant is spray inoculated on soybean plants as compared to the wild type parental strain [20]. In Pseudomonas levan is synthesized by bacterial extracellular enzymes levansucrases (lsc) (EC 2.4.1.10), whose mechanism involve the breakage of the glycosidic linkage in the sucrose molecule, resulting in the formation of a covalent fructosyl-enzyme intermediate and the release of the glucose moiety. The fructosyl moiety is then transferred from the enzyme to an acceptor molecule; as a result, the acceptor is elongated in one fructosyl unit (polymerization). When a water molecule acts as acceptor of the fructosyl intermediate, fructose is released into the reaction media (hydrolysis) [16]. Interestingly, meanwhile most bacteria species harbour a unique lsc coding gene, the members of Pssc, possess up to three. An explanation for the occurrence of multiple $I s c$ copies is yet to be found $[1,16,21]$.

To date the best characterized lscs of Pseudomonas are lsc1, lsc2 and lsc3 from Psudomonas syringae pv tomato DC3000 [22] and lscA, IscB and $\operatorname{lscC}$ from P. syringae pv. glycinea PG4180 [20]. LscA/2 is usually present in a single copy in $P$. syringae genomes but its variants have been found in other enterobacteriaceae, including the phytopathogenic species Erwinia amylovora, leading to the hypothesis that it has been exchanged by HGT (Horizontal Gene Transfer) among genera [21]. On the contrary the other two levansucrase coding genes $l s c B / 1$ and $l s c C /$ 3 , have been reported to occur only in $P$. syringae pathovars. In DC3000 they share a sequence identity of 95\% both at nucleotide and amino acidic level, meanwhile in PG4180 they share a sequence identity of $98 \%$ and $99 \%$ at nucleotidic and amino acidic levels, respectively, and are referred to as "variant BC alleles" [21]. Mutagenesis experiments of lsc2 and lsc3 demonstrate that Asp62, Asp219 and Glu303 are the crucial amino acids for activity: in the active site they form the catalytic triad in which Asp62 acts as nucleophile, Glu303 as acid/base catalyst and Asp219 as stabilizer [23]. Other amino acids besides the catalytic triad are important for $1 s c$, therefore studying their impact could be very important to lay the basis for a functional characterization of these enzymes [24,25]. In addition, other factors such as temperature, substrate or enzyme concentration and the presence of solvents or salts can modify their activity. For several lscs of Pseudomonas bacteria the $\mathrm{pH}$ optima are rather similar and close to 6.0 even if in some cases their activity shows pH fluctuation $[23,26]$. Finally, they are resistant to high temperature confirming their great stability as to be expected for bacterial extracellular enzymes [23,27].

This work starts from the comparison of the lsc genes sequences reported in the NCBI databases: according to which the gene NZ708_RS29580, putatively codes for a plasmidic lsc of Psa3 strain ICMP 18708. If it is functional, it would possess a 45 nucleotide region at the $5^{\prime}$ end that would render it unique not only respect to the homologous genes of the other Psa biovars (and Pfm), but within the Pssc.

Since levan production, size and structure could be important also for pathogenesis and knowing the role of the different lscs present in Psa3 could be crucial for understanding its great virulence, by cloning and expressing two new lsc genes from Psa3 in E. coli, aim of the present study was to determine for the first time if they produce functional protein products as well as their optimum of activity and kinetic parameters in different conditions.

\section{Materials and methods}

\subsection{Nucleotide sequence analysis and comparison}

Strain KL103 was isolated from a kiwi leaf on KBC semi-selective medium [28] and characterized as Psa3 according to the LOPAT determinative scheme [29] and by MLSA sequencing four housekeeping gene fragments $p f k, r p o D$, cts and pgi following the procedures for DNA extraction, PCR amplification and direct sequencing as previously described [3].

Database searches were carried out using BLAST algorithms available on the National Center for Biotechnology Information (NCBI, http://www.ncbi.nlm.nih.gov) using the nucleotide sequences of the IscA (AF037443), lscB (AF345638) and lscC (AF346402) levansucrase coding sequences of $P$. glycinea PG4180 as query. The homologous sequences of the 3 selected genes including their flanking regions, of complete genomes of Pseudomonas syringae pv. actinidiae: eight biovar 3, one biovar 1 (Psa1), one biovar 5 (Psa5), were retrieved and aligned using Muscle multiple sequence alignment tool to estimate intra and inter pathovars similarities (implemented in Mega X [30]). To obtain the corresponding sequences from Psa3 KL103, primers listed in Table S1 were designed. To amplify the KL103 putative $l s c$ genes ( $l s c \alpha, l s c \beta$, lsc $\gamma$ ), reagent mix composition was: $1 \times$ PCR buffer (New England BioLabs), $0.2 \mathrm{mM}$ each dNTP (Thermo Scientific), 1.25 U of Q5 Hot Start High-Fidelity DNA Polymerase (New England BioLabs), $0.2 \mu \mathrm{M}$ of each primer and $50 \mathrm{ng}$ of template DNA. Thermal cycling consisted of $3 \mathrm{~min}$ at $95{ }^{\circ} \mathrm{C}$ for initial denaturation, 35 cycles of denaturation at $95^{\circ} \mathrm{C}$ for $30 \mathrm{~s}$, annealing at $62{ }^{\circ} \mathrm{C}$ for $30 \mathrm{~s}$, extension at $72{ }^{\circ} \mathrm{C}$ for $2 \mathrm{~min}$, followed by $10 \mathrm{~min}$ at $72{ }^{\circ} \mathrm{C}$ for final extension. All PCR products obtained from Psa3 KL103 were purified using ExoSAP-IT (Usb Corporation) according to the manufacturer's protocol and subjected to direct sequencing. Nucleotide sequences were visualized using CHROMAS LITE 2.01 (Technelysium) and identity searches were performed using software tools BlastN and BlastP available from the NCBI. Isc nucleotide sequences were aligned using MUSCLE and a cladogram was constructed (1235 positions in the final dataset) using the Neighbor-Joining method and the Kimura 2 parameter model of evolution.

\subsection{Isc $\gamma$ mRNA analysis}

A preliminary trial was performed to check if $l s c \gamma$ gene is actually expressed in Psa3 KL103. The strain was grown in $100 \mathrm{~mL}$ of NB or NB with $5 \%(\mathrm{w} / \mathrm{v})$ sucrose (NBS) at $25{ }^{\circ} \mathrm{C}, 200 \mathrm{rpm}$, for $72 \mathrm{~h}$. At different time point ( $24 \mathrm{~h}, 48 \mathrm{~h}$ and $72 \mathrm{~h}$ ), $1 \mathrm{~mL}$ of culture was centrifuged at $10,000 \mathrm{~g}$ for $2 \mathrm{~min}$ and pellet subjected to total RNA extraction by NucleoZOL (MACHEREY-NAGEL) following manufacturer instruction. Final RNA pellet was recovered by $50 \mu \mathrm{L}$ of nuclease free water and it was subsequently subjected to nucleic acid quantification through Nanodrop spectrophotometer ND-1000. Total RNA (18 $\mu$ g) was DNase (MACHEREY-NAGEL, rDNase, 740963) treated and reverse transcribed by RevertAid First Strand cDNA Synthesis Kit (Thermo Scientific) using oligo(dT). cDNAs, were PCR amplified (DreamTaq, Thermo Scientific) using primers plasmL1/R1 (Table S1) with the following procedure: $2 \mathrm{~min}$ at $94{ }^{\circ} \mathrm{C}$ for initial denaturation, 40 cycles of denaturation at $94{ }^{\circ} \mathrm{C}$ for $30 \mathrm{~s}$, annealing at $62{ }^{\circ} \mathrm{C}$ for $30 \mathrm{~s}$, extension at $72{ }^{\circ} \mathrm{C}$ for $1 \mathrm{~min}$, followed by $5 \mathrm{~min}$ at $72^{\circ} \mathrm{C}$ for final extension. PCR products were visualized on $1.3 \%(\mathrm{w} / \mathrm{v})$ agarose gel. DNAse-treated RNA was used as control for DNA contaminations.

\subsection{Lsc $\beta$ and lsc $\gamma$ cloning in $p G E M-T$ and E. coli $5 \alpha$}

The coding regions of $l s c \beta$ and $l s c \gamma$ sequences and $\sim 100$ bp of $5^{\prime}$ and $3^{\prime}$ noncoding sequences were PCR-amplified from lysed cells of Psa3 KL103 using primers reported in Table S1. PCR products were purified from agarose gel troughs QIAquick Gel Extraction Kit (QIAGEN) and then cloned in pGEM-T vector using the pGEM ${ }^{\circledR}-\mathrm{T}$ Easy Vector Systems (PROMEGA) following the manufacture instructions. Finally, plasmids were used to transform the 5-alpha competent E. coli cells (New England BioLabs) and colonies were selected with blue/white screening and standard ampicillin selection. Correct DNA insertion was checked by sequencing using primers T7/SP6. 


\subsection{Lsc $\beta$ and lsc $\gamma$ cloning in pNIC28 and E. coli BL21}

Using ligation-independent cloning (LIC) and primers reported in Table S1, the $l s c \beta$ and $l s c \gamma$ genes derived from the previously obtained pGEM plasmids, were cloned in pNIC28-Bsa4 systems as reported by Vega et al. [31].

Obtained recombinant plasmids were used to transform 5-alpha competent $E$. coli cells and colonies from LB agar plates, supplemented with $50 \mu \mathrm{g} / \mathrm{mL}$ kanamycin and $5 \%(\mathrm{w} / \mathrm{v})$ sucrose, were cultured, and plasmid purification was performed using the NucleoSpin plasmid extraction kit (MACHEREY-NAGEL). Transformants were characterized by colony PCR screening using the primers for the inserts and the correct nucleotide sequences were verified by DNA sequencing. Purified plasmids were than used to transform E. coli BL21 (DE3) cells (New England Biolabs).

\subsection{Production, purification, and characterization of recombinant} levansucrases

\subsubsection{Production and purification}

Expression and purification of recombinant lsc $\beta$ and lsc $\gamma$ were performed in the same manner. E. coli BL21 cells were grown at $37{ }^{\circ} \mathrm{C}$ under shaking in $1 \mathrm{~L}$ of LB broth with $50 \mu \mathrm{g} / \mathrm{mL}$ kanamycin; at O.D. $600=0.6$. Proteins expression was induced by $0.4 \mathrm{mM}$ IPTG for $20 \mathrm{~h}$ at $18{ }^{\circ} \mathrm{C}$. Then cells were centrifuged at $2000 \mathrm{~g}$ for $20 \mathrm{~min}$ and pellets were resuspended in $40 \mathrm{~mL}$ of $50 \mathrm{mM}$ sodium phosphate buffer pH 6.0, $300 \mathrm{mM} \mathrm{NaCl}, 10 \%$ (v/v) glycerol and $10 \mathrm{mM}$ imidazole (Buffer A) [22]. Bacterial cells were harvested by 5 sonication steps of $30 \mathrm{~s}$ at $50 \mathrm{kHz}$ and centrifuged again at $13,000 \mathrm{~g}$ for $25 \mathrm{~min}$ at $4{ }^{\circ} \mathrm{C}$.

$\operatorname{lsc} \beta$ and lsc $\gamma$ were purified from the whole cell lysate by IMAC Sepharose High Performance (Ge Healthcare) charged with $\mathrm{Ni}^{2+}$.

The lysate $(40 \mathrm{~mL})$ was applied to a $10 \mathrm{~mL} \mathrm{Ni}^{2+}$-resin in a gravity column equilibrated with buffer $A$. The column was washed with buffer A with $25 \mathrm{mM}$ imidazole and then eluted with buffer A with $250 \mathrm{mM}$ imidazole and the pooled fractions were concentrated to $5 \mathrm{~mL}$ for TEV (Tobacco Etch Virus protease) treatment to remove the $6 \mathrm{His}$-tag.TEV treatment was performed at $37^{\circ} \mathrm{C}$ in $50 \mathrm{mM} \mathrm{Tris/HCl} \mathrm{pH} \mathrm{8,10 \%} \mathrm{(v/v)}$ glycerol for $20 \mathrm{~h}$. Subsequently, sample were applied again on $\mathrm{Ni}^{2+}$ resin in a gravity column for un-catted and tag removing. Finally, lscs were further purified by gel chromatography on a HiLoad 16/600 Superdex 200 pg column driven by an Akta Pure 25 L system (GE Healthcare, Waukesha, WI, USA) at a flowrate of $1 \mathrm{~mL} / \mathrm{min}$ and they were step eluted with $50 \mathrm{mM}$ Tris/ $\mathrm{HCl} \mathrm{pH} 8.0$ and $300 \mathrm{mM} \mathrm{NaCl}$. Proteins were collected ( 50 fractions, $2 \mathrm{~mL}$ each), and analysed by SDSPAGE, using 4-20\% Mini-Protean TGX Precast polyacrylamide gels (Bio-Rad, Hercules, CA, USA).

\subsubsection{Mass spectrometry analysis}

Mass spectrometry analysis were performed by Mass Spectrometry Center (CISM) of Florence University as reported in Vega et al., 2019 using chymotrypsin as protease.

\subsubsection{Protein quantitation}

Proteins quantitation were performed by bicinchoninic acid method (BCA, Pierce Chemical, Rockford, IL) using BSA as protein standard.

\subsubsection{Analytical gel-filtration}

Analytical gel-filtration was carried out as reported in Vega et al. [31] with slight modifications. Briefly, lscs samples and standard proteins of know molecular weight (thyroglobulin $669 \mathrm{kDa}$, apoferritin $443 \mathrm{kDa}$, alcohol dehydrogenase $150 \mathrm{kDa}$, BSA $66 \mathrm{kDa}$, carbonic anhydrase $29 \mathrm{kDa}$ and a-lactalbumin $14 \mathrm{kDa}$ ) were loaded in a Superdex 200 Increase 10/ 300 GL column (GE Healthcare) equilibrated with Tris/HCl pH 8.0, NaCl $300 \mathrm{mM}$ buffer at $4{ }^{\circ} \mathrm{C}$ and run by Akta Pure $25 \mathrm{~L}$. Elution volumes were taken as the volumes of buffer passed through the column between sample injection and the point of highest absorbance. A plot of elution volume vs. $\log [\mathrm{MW}]$ (data not shown) was obtained with the standards data points and fitted to a linear regression curve [32]. The elution volumes measured for both the lscs were then interpolated into the resulting standard curve to obtain the corresponding MW.

\subsubsection{Dynamic light scattering}

Size distribution analysis was performed at $25{ }^{\circ} \mathrm{C}$ with a Malvern Zetasizer Nano S Dynamic Light Scattering (DLS) device (Malvern Panalytical, Malvern, United Kingdom) using proteins at a concentration of $0.5 \mathrm{mg} / \mathrm{mL}$ in $50 \mathrm{mM}$ Bis/Tris pH 7.0 buffer. Each sample was centrifuged at $13,000 \mathrm{~g}$ for $15 \mathrm{~min}$ at $4{ }^{\circ} \mathrm{C}$, filtered with Whatman Anotop $0.02 \mu \mathrm{m}$ cut-off filters (Millipore Sigma), and analysed considering the refraction index and viscosity of the dispersant. A $10-\mathrm{mm}$ reduced volume plastic cell was used.

\subsection{6. $C D$ spectra}

Analysis was performed at $1 \mathrm{mg} / \mathrm{mL}$ of proteins in $12.5 \mathrm{mM} \mathrm{Tris} / \mathrm{HCl}$ $\mathrm{pH} 8.0, \mathrm{NaCl} 20 \mathrm{mM}$. CD spectra were recorded in the far-UV region from 190 to $260 \mathrm{~nm}$ using a JASCO J-810 spectropolarimeter (Tokyo, Japan). The spectra were acquired using a $0.1 \mathrm{~mm}$ path length quartz cell, a band width of $1 \mathrm{~nm}$, a response time of $0.5 \mathrm{~s}$, a data pitch of $0.5 \mathrm{~nm}$ and a scanning speed of $20 \mathrm{~nm} / \mathrm{min}$. Each spectrum was the average of 16 consecutive scans followed by subtraction of the blank spectra.

\subsubsection{Differential scanning fluorimetry}

Differential scanning fluorimetry (DSF) was performed using a BioRad CFX96 (Biorad) by selecting the FAM (FRET) filter. Analysis was performed with $0.1 \mathrm{mg} / \mathrm{mL}$ of protein and 1:500 of SYPRO Orange (ThermoFisher Scientific, Waltham, MA, USA) in $50 \mathrm{mM}$ Sodium Acetate pH 5.0 or $50 \mathrm{mM}$ Bis/Tris pH 7.0 buffers in a final volume of $25 \mu \mathrm{L}$. All samples were prepared in triplicate. The samples where heated with a ramp speed, which provides a 2 min pause at $25^{\circ} \mathrm{C}$, followed by a ramp to $95^{\circ} \mathrm{C}$, increasing the temperature of $1{ }^{\circ} \mathrm{C} / \mathrm{min}$. The SYPRO Orange fluorescence was plotted versus temperature (melting curve) and the resulting plot converted into its first order derivative, which provided the melting temperature ( $\mathrm{Tm})$.

\subsection{Sucrose hydrolysis activity of proteins}

Sucrose hydrolysis activities of lsc $\beta$ and lsc $\gamma$ were checked measuring the amount of glucose liberated during incubation with sucrose. There are several useful methods for glucose detection [33], between them we chose the DiNitroSalicylic acid (DNS) method because previously used in lsc reactions [22].

\subsection{1. $\mathrm{pH}$ dependence}

Experiments were performed at $0.03 \mu \mathrm{g} / \mu \mathrm{L}$ enzymes concentration with $150 \mathrm{mM}$ sucrose in buffer at different $\mathrm{pH}$. Total volume assays were $100 \mu \mathrm{L}$ and the total ionic strength of each buffer were $100 \mathrm{mM}$. Used buffer: $\mathrm{pH} 4.0$ and $5.050 \mathrm{mM}$ sodium acetate; pH 6.0 and 7.0 $50 \mathrm{mM}$ Bis/Tris; pH 8.0 and $9.050 \mathrm{mM}$ Tris. Reactions were conducted at $37{ }^{\circ} \mathrm{C}$ for $10 \mathrm{~min}$ and then stopped boiling samples. Finally, DNS method was used to determine the glucose.

\subsubsection{Ionic strength dependence}

Experiments were performed at $0.03 \mu \mathrm{g} / \mu \mathrm{L}$ enzymes concentration with $150 \mathrm{mM}$ sucrose in $50 \mathrm{mM}$ Bis/Tris pH 7.0 buffer. Different concentrations of $\mathrm{NaCl}$ were added to each tube starting from 0 to $1 \mathrm{M}$. Total analysis volume was $100 \mu \mathrm{L}$ and tests were done at $37^{\circ} \mathrm{C}$ for $10 \mathrm{~min}$. After, reactions were stopped, and glucose concentrations were determined by DNS method.

\subsubsection{Temperature dependence}

Experiments were performed at $0.03 \mu \mathrm{g} / \mu \mathrm{L}$ enzymes concentration with $150 \mathrm{mM}$ sucrose in a buffer $50 \mathrm{mM}$ Bis/Tris pH 7.0, or $50 \mathrm{mM}$ sodium acetate $\mathrm{pH}$ 5.0. Total analysis volume was $100 \mu \mathrm{L}$ and tests were 
done at $5{ }^{\circ} \mathrm{C}, 15^{\circ} \mathrm{C}, 25^{\circ} \mathrm{C}, 37^{\circ} \mathrm{C}, 45^{\circ} \mathrm{C}, 55^{\circ} \mathrm{C}$ and $65^{\circ} \mathrm{C}$ for $10 \mathrm{~min}$. After, reactions were stopped, and glucose concentrations were determined by DNS method.

\subsubsection{Km determinations}

Experiments were performed at $0.1 \mu \mathrm{g} / \mu \mathrm{L}$ enzymes concentration with variable concentrations of sucrose in a buffer $50 \mathrm{mM}$ Bis/Tris $\mathrm{pH} 7.0$ or $50 \mathrm{mM}$ sodium acetate $\mathrm{pH} 5.0$, at $37^{\circ} \mathrm{C}$ for $10 \mathrm{~min}$. Reaction rate was determined for each assay and reported on MichaelisMenten chart to determine $\mathrm{K}_{\mathrm{m}}$ and $\mathrm{V}_{\mathrm{max}}$. $\mathrm{k}_{\text {cat }}$ were obtained using the following equation:

$\mathrm{kcat}=\frac{\mathrm{Vmax}}{[\mathrm{E}] \mathrm{tot}}$

where Vmax was the maximum velocity of the reaction and [E]tot was the total enzyme concentration.

\subsubsection{DNS}

Glucose concentration was determined by DNS method as reported by Goncalves et al. 2010 [34] with slight modifications. Briefly, reaction was carried out in 96 wells plate, adding $25 \mu \mathrm{L}$ of DNS reagent to $25 \mu \mathrm{L}$ of sample, or distilled water (blank). Subsequently, in order to perform the reaction, the microtiter plate, with cap, was placed at $95{ }^{\circ} \mathrm{C}$ for $10 \mathrm{~min}$, then it was placed on ice and $250 \mu \mathrm{L}$ of distilled water were immediately added to each well. Calibration curve was obtained starting from 0 to $250 \mu \mathrm{g}$ of glucose. Finally, samples absorbances were read at $540 \mathrm{~nm}$ in a BioTek Synergy H1 Hybrid Multi-Mode Reader.

\subsection{Polymerization activity of proteins}

Levan synthesis kinetics was monitored in a turbidity assay on microtitre plate [22]. Reaction was performed at $37^{\circ} \mathrm{C}$ in $200 \mu \mathrm{L}$ of buffer at pH 5.0 (50 mM sodium acetate) or 7.0 (50 mM Bis/Tris), containing different concentrations of sucrose and $10 \mu \mathrm{g}$ of purified levansucrases protein per $\mathrm{mL}$ of reaction mixture. Turbidity of the samples at $400 \mathrm{~nm}$ was recorded every 5 min using a BioTek Synergy H1 Hybrid Multi-Mode Reader.

\section{8. $L s c \beta$ and $l s c \gamma$ expression analysis}

Template-specific primers and probe were designed for $l s c \beta$ and $l s c \gamma$ of Psa3 KL103 (Table S1) and the specificity of each set was verified against each other using $50 \mathrm{ng}$ of purified pGEM plasmids containing the insert of interest. Strain KL103 was grown on nutrient agar plates at $25^{\circ} \mathrm{C}$ for $72 \mathrm{~h}$, resuspended in sterile distilled water at a concentration of approximately $3.6 \times 10^{5} \mathrm{cfu} / \mathrm{mL}\left(\mathrm{OD}_{600}=0.07\right)$ and $100 \mu \mathrm{L}$ of the resulting suspension was used to inoculate $100 \mathrm{~mL}$ of NB. The culture was grown on a rotary shaker at $25^{\circ} \mathrm{C}$ and $200 \mathrm{rpm}$ for 10 days. At 0 h, 4 h, 10 h, 12 h, 24 h, 36 h, 48 h, 72 h, 144 h and 240 h, pH and cells number were determined by plate count method, and RNA extracted from $0.5 \mathrm{~mL}$ of culture. For $\mathrm{pH}$ determination, $3 \mathrm{~mL}$ of culture were centrifuged at $12,000 \mathrm{~g}$ for $5 \mathrm{~min}$ and supernatant analysed by $\mathrm{pH}$ meter.

RNA was extracted by NucleoZOL (MACHEREY-NAGEL) following the manufacturer instructions and quantified via Nanodrop spectrophotometer ND-1000 (Nanodrop). $600 \mathrm{ng}$ of total RNAs were DNase treated (MACHEREY-NAGEL, rDNase, 740963) for $1 \mathrm{~h}$ at $37^{\circ} \mathrm{C}$ and then, a RTPCR was performed on $300 \mathrm{ng}$ of DNAse treated-RNA using the RevertAid First Strand cDNA Synthesis Kit (Thermo Scientific) as recommended by the manufacturer. The gene specific $l s c \beta$ and $l s c \gamma$ primers and probe were used to check for presence of mRNA by PCR using cDNA as template. DNAse-treated RNA was used as control for DNA contaminations.

Real-Time PCR was performed in a Biorad CFX96 instrument using the following thermocycler program: 1 cycle of $95^{\circ} \mathrm{C}$ for $2 \mathrm{~min}$; 40 cycles of $95{ }^{\circ} \mathrm{C}$ for $15 \mathrm{~s}$ and $62{ }^{\circ} \mathrm{C}$ for $1 \mathrm{~min}$. Each sample was run in triplicate using GoTaq ${ }^{\circledR}$ Probe qPCR Master-mix (Promega), and primers and TaqMan probe sets are reported in Table S1. Reaction volume was $15 \mu \mathrm{L}$.

\subsubsection{Absolute quantification real-time $P C R$ assays}

pGEM-lsc $\beta$ and pGEM-lsc $\gamma$ plasmids were used to build a standard curve for absolute mRNA quantifications for the expression analysis of the two levansucrases. $20 \mathrm{ng}$ of circular plasmids were linearized with $B S A I$ (NEB) restriction enzyme following manufacturer instructions and used to build an eight point standard curve ranging from $16 \mathrm{ng}$ to $0.16 \mathrm{fg}$. $15 \mu \mathrm{L}$ reactions for all standards were run in triplicate under the same conditions of samples. Average Ct values and log (ng) values were used to obtain a linear regression equation allowing for calculation of ng of cDNAs of $l s c \beta$ and $l s c \gamma$ in Psa3 KL103 [35].

\section{Results}

\subsection{Nucleotide sequence analysis and comparison}

All Psa3 complete genomes considered in this study as well as Psa1 ICMP 9853, possess 3 putative lsc coding genes. Invariably in Psa3, two lscs are chromosome located (Isc $\alpha$ and $l s c \beta$ ) meanwhile one is plasmid borne (lsc $\gamma$ ). On the contrary, strain MAFF212063 (Psa5) possess only two putative lsc coding genes which are both on the chromosome. When tested for presence of the lsc $\alpha$ gene sequence, the expected amplicon was yield from strain Psa3 KL103 DNA and its length was 1248 bp. The nucleotide sequence showed $87 \%$ identity with $P$. syringae pv. glycinea PG4180, 99\% with Psa1 (ICMP 9853), Psa2 (ICMP19072) Psa5 (MAFF212063) and P. syringae pv. actinidifoliorum (CFBP8039), and $100 \%$ with all Psa3 whole genomes considered in this study (data not shown). Noticeably, in all Psa3 homologous sequences, a G to A transition was found $187 \mathrm{bp}$ downstream of the translation initiation codon of this gene and in silico analyses indicated that the deriving nucleotide mutation would generate an early termination codon implying that this gene is most likely not functional in Psa3 (Fig. S1). In accordance with Psa3 complete genomes, the two others predicted lsc genes were isolated from strain KL103 by PCR, and their translated sequence encodes for proteins of 431(WP_017684964) (hereafter called lsc $\beta$ ) and 430 (WP_017685048) (called lsc $\gamma$ ) amino acidic residues, respectively. 1sc $\beta$, whose genetic determinant is chromosome located in all Psa3 genomes, shares 98\% identities with either $1 \mathrm{scB}$ or $1 \mathrm{scC}$ of PG4180 which however are 99\% identical one to each other. On the contrary the first 14 predicted amino acid residues located at the putative $\mathrm{N}$-terminus of the lsc $\gamma$ protein (MIAGRRHFDCRPLH) appear to be unique. The genetic determinant of $1 \mathrm{sc} \gamma$ is on a large plasmid (74,432 bp, p18708 in Psa3 ICMP18708; [36]) carried by all Psa3 and the first $14 \mathrm{~N}$-terminal aminoacids of the encoded protein are different not only from the corresponding N-terminal domain of $1 s c \beta$ (Fig. 1) but also from that of other Psa as well as P. syringae levansucrases annotated in the prok_complete_genomes database (data not shown). Using BLAST we searched for the presence of signal peptide consensus sequence against the NCBI's non-redundant (NR) protein database but no significant score was obtained (data not shown). It is noteworthy that despite its localization on mobile genetic element, $l s c \gamma$ coding gene is highly conserved without any sequence variation in all Psa3 complete genomes. The predicted catalytic motifs I, II and III of PG4180 BC variants were found in both lsc $\beta$ and lsc $\gamma$ proteins (Fig. 1).

\subsection{Search of lsc $\gamma$ mRNA presence in Psa3}

Aimed to verify if the lsc $\gamma$ gene (NZ708_RS29580) was expressed in Psa3, bacteria were grown on NB and NBS for $72 \mathrm{~h}$ and then checked for the presence of the mRNA. Iscy specific primers produced a 231 nucleotide fragment from cDNA, and Sanger sequencing results confirmed the identity both when Psa3 KL103 was grown on NB or NBS (data not 


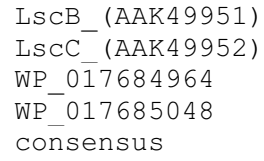

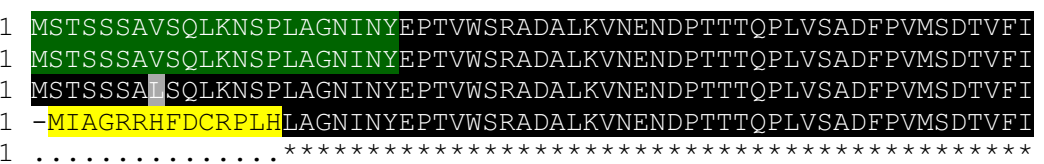
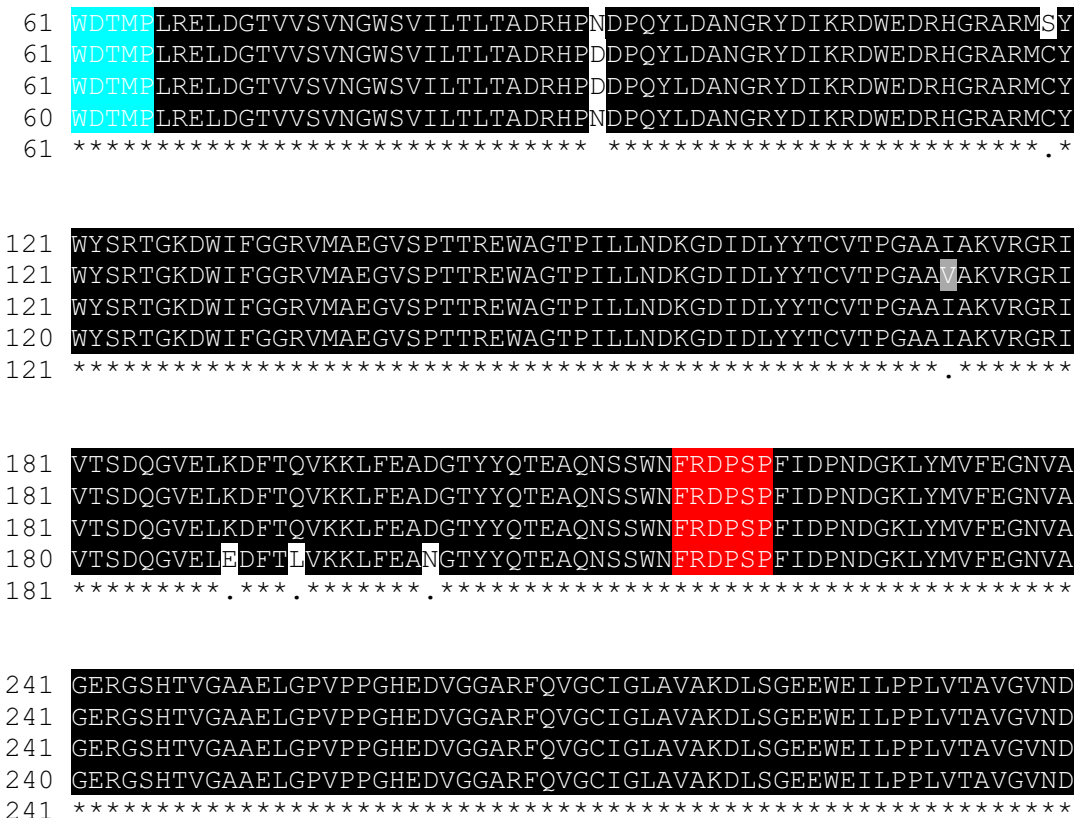

301

301

301

300

301

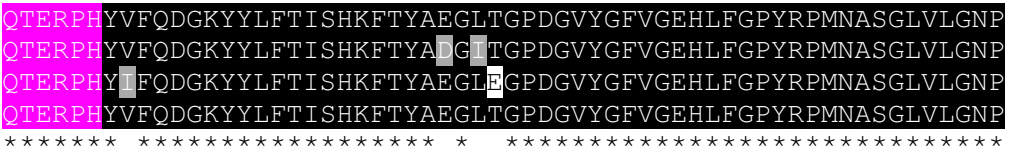

361

361

361

360

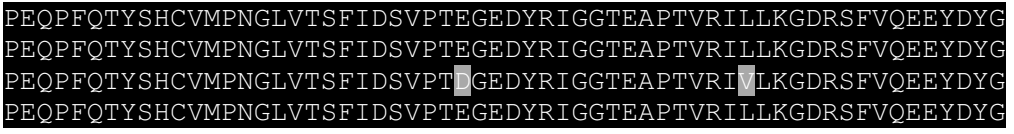

361

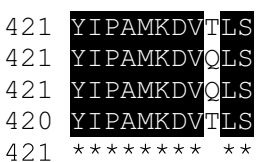

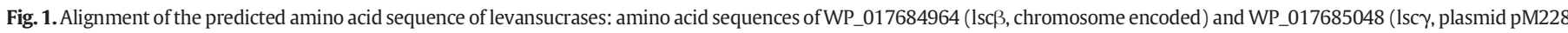

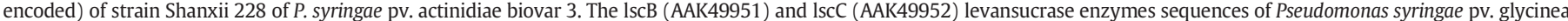

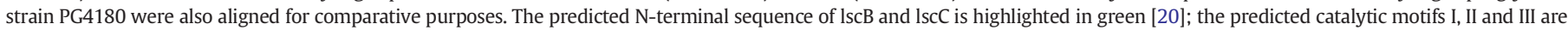

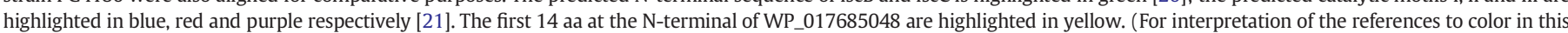
figure legend, the reader is referred to the web version of this article.)

shown). Thus, this gene was effectively transcripted by the bacterium both in presence and absence of sucrose in the medium.

\subsection{Cloning of $l s c \beta$ and lsc $\gamma$ genes}

lsc $\beta$ and $l s c \gamma$ gene were cloned in the pNIC28 expression system and recombinants were produced in E. coli BL21 as described in experimental procedures.

To check the ability of cloned genes to produce levan, the BL21 pNIC28-lsc $\beta$, BL21 pNIC28-lsc $\gamma$ and BL21 wild type cells were plated in LB agar with $5 \%$ sucrose. Bacteria were grown for $24 \mathrm{~h}$ at $37{ }^{\circ} \mathrm{C}$ and then at $4{ }^{\circ} \mathrm{C}$ for $48 \mathrm{~h}$. After $72 \mathrm{~h}$, BL21 cells with recombinant levansucrase showed the typical colony shape of levan positive bacteria but not the wild type BL21, suggesting the correct functionality of both lsc $\gamma$ e lsc $\beta$ enzymes (Fig. 2).

\subsection{Expression and structural characterization of recombinant levansucrases from Psa}

Recombinant $\operatorname{lsc} \beta$ and $1 s c \gamma$ proteins were obtained through the same purification procedure. Briefly, the 6 His-tagged proteins were recovered after bacterial lysis and purified by $\mathrm{Ni}^{2+}$-affinity column. Tag was deleted from proteins by enzymatic cleavage by TEV (Tobacco Etch Virus protease) and removed through another passage in $\mathrm{Ni}^{2+}$ - 


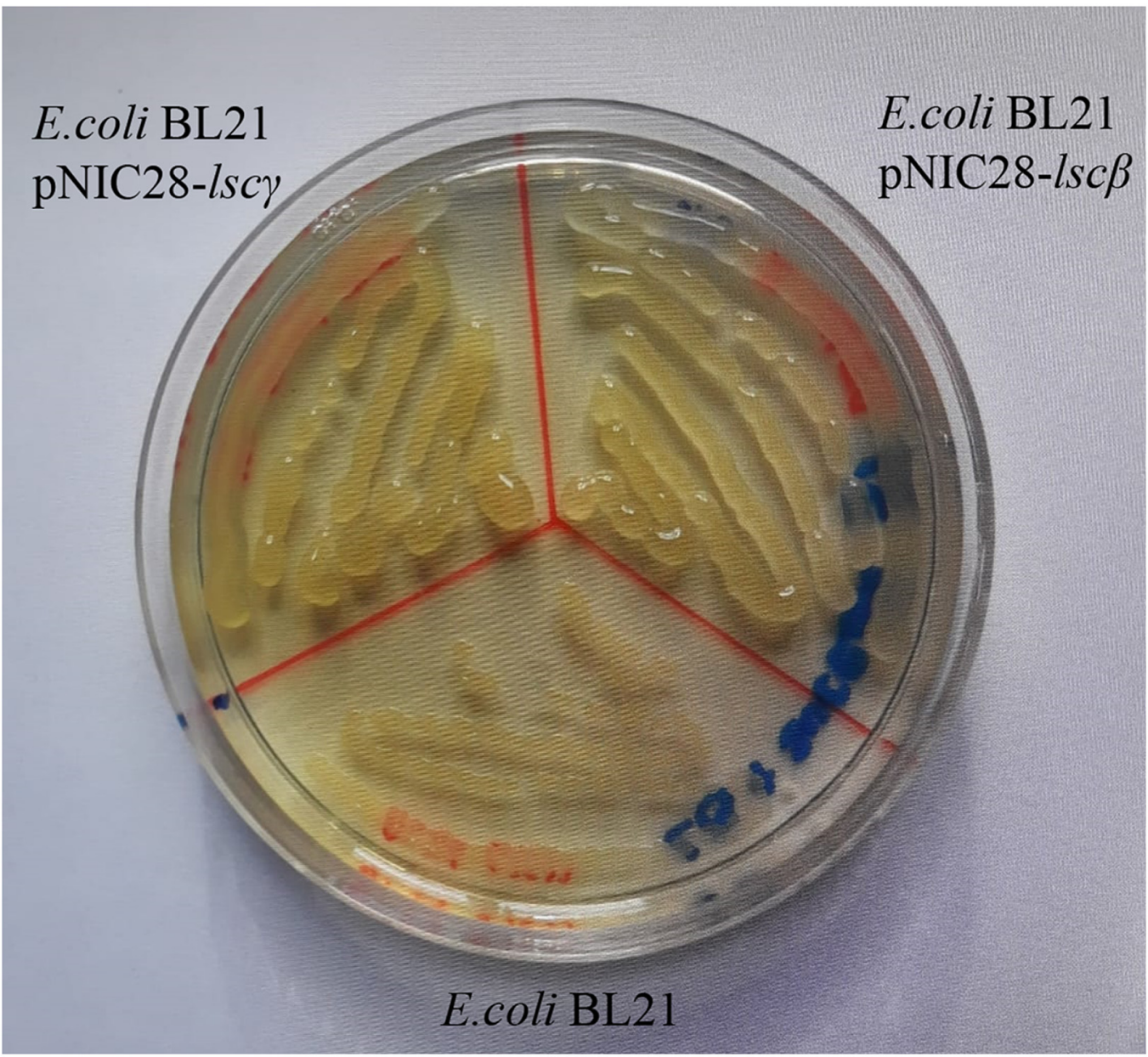

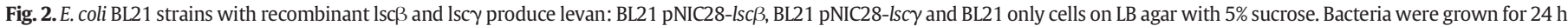
at $37^{\circ} \mathrm{C}$ and then at $4{ }^{\circ} \mathrm{C}$ for $48 \mathrm{~h}$. BL21 pNIC28-lsc $\beta$, BL21 pNIC28-lsc $\gamma$ showed the typical colony shape of levan positive bacteria while wild type BL21 not.

affinity column. Finally, proteins were further purified by size exclusion column. The purification procedure allowed to obtain $80 \mathrm{mg}$ and $50 \mathrm{mg}$ of pure protein for $\operatorname{lsc} \beta$ and lsc $\gamma$, respectively.

Proteins purity and molecular weight were checked by SDS-PAGE (Fig. S2) and further confirmed by mass spectrometry analysis (Fig. S3). Proteins were digested with chymotrypsin which permitted the identification of several protein fragments that were assigned to portions of the sequences, validating the identity of the two proteins (Fig. S3a). The amino acid sequences of $\operatorname{lsc} \beta$ and $\operatorname{lsc} \gamma$ is very similar and the main differences are at the $\mathrm{N}$-terminal regions (Fig. 1). Although the fragments obtained after chymotrypsin digestion did not cover the $\mathrm{N}$-terminus, the different fragmentations allowed to distinguish the two proteins (Fig. S3b).

Some studies reported that lsc could be found in dimeric or monomeric form [37]. In order to analyse the proteins behaviour in solution, we estimate the molecular weight of the particles by analytical Gel Filtration. Fig. 3a showed the chromatogram of the two proteins at $\mathrm{pH} 7.0$ which presented similar elution volume, indicating that the two proteins were in the same form.

A calibration curve was obtained by plotting the elution volumes of 6 known proteins $v s$ their MW in logarithmic form (data not shown). This allows us to estimate the MW of lsc $\beta$ and lsc $\gamma$ which results $85.8 \pm 4.8$ and $86.6 \pm 6.3 \mathrm{kDa}$, respectively. Because the MW of each $1 \mathrm{sc} \beta$ and $\mathrm{lsc} \gamma$ monomer is $47.6 \mathrm{kDa}$, this apparent MW is consistent with a dimer. The ability of proteins to form functional dimers was confirmed by dynamic light scattering (DLS) analysis (Fig. 3b). The hydrodynamic diameter of the two proteins was similar and compatible with the dimeric form of the proteins $(\operatorname{lsc} \beta 8.7 \pm 1 \AA$ lsc $\gamma$ and $10.1 \pm 1 \AA$ ).
To further characterize $1 s c \beta$ and lsc $\gamma$, far-UV-CD spectra of the proteins were obtained (Fig. 3c). They were very similar and presented the analogue shape of other lscs from Gram negative bacteria [38]. We performed the deconvolution of these spectra using the BeStSel algorithm (http://bestsel.elte.hu) obtaining the $45 \%$ and $46 \%$ of $\beta$-sheets for lsc $\beta$ and lsc $\gamma$, respectively (data not shown), confirming the probable five-bladed $\beta$-propeller architecture characteristic of many lscs [24].

Another typical feature of lscs is the high stability; in fact, they are extracellular proteins subjected to constant stress, such as changing in $\mathrm{pH}$, salt and temperature and they needed to be stable for a correct function [23]. Therefore, stability of $1 \mathrm{sc} \beta$ and $1 \mathrm{sc} \gamma$ was determined by DSF, which allows the rapid and sensitive assessment of protein thermal stability. Using Sypro-orange we were able to determine the $T_{m}$ of proteins calculating the first derivative of DSF curve obtained (Fig. 3d). Our data revealed that $\operatorname{lsc} \beta$ and $1 \mathrm{sc} \gamma$ had a Tm respectively of $60.0 \pm 0.0^{\circ} \mathrm{C}$ and $55 \pm 0.0^{\circ} \mathrm{C}$, confirming the high thermal stability of lscs [23].

Finally, through the Expasy SWISS-MODEL tools (https://swissmodel. expasy.org/interactive), which use a comparative approach to generate 3D models of a protein, we obtained a 3D models of both $1 s c \beta$ and lsc $\gamma$ which appear quite similar to each other and to other lscs (Fig. S4).

\subsection{Sucrose hydrolysis activity of $l s c \beta$ and $l s c \gamma$}

The sucrose splitting activity was performed using $0.63 \mu \mathrm{M}$ of enzymes ( $1 \mathrm{sc} \beta$ and $1 \mathrm{sc} \gamma$ ), and $150 \mathrm{mM}$ sucrose and incubation time of $10 \mathrm{~min}$.

Firstly, the effect of pH on enzymatic activity was investigated. Both lsc enzymes show the maximal activity in the 5-7 pH range, while the activity of enzymes decreases at $\mathrm{pH}$ values lower that 5 and higher 
a

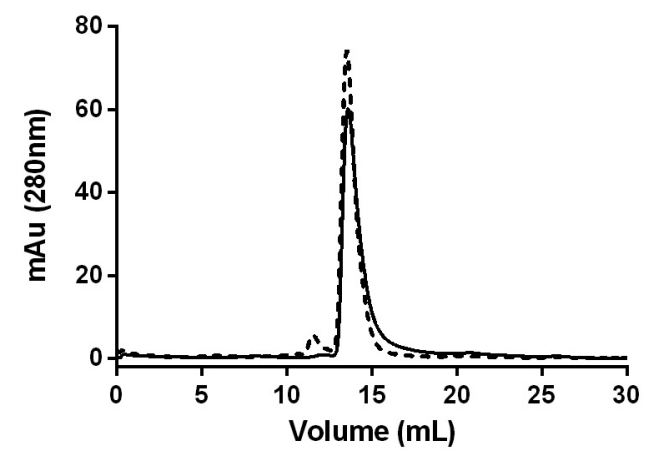

$---\mid \operatorname{lsc} \gamma$

$-\operatorname{Isc} \beta$ b

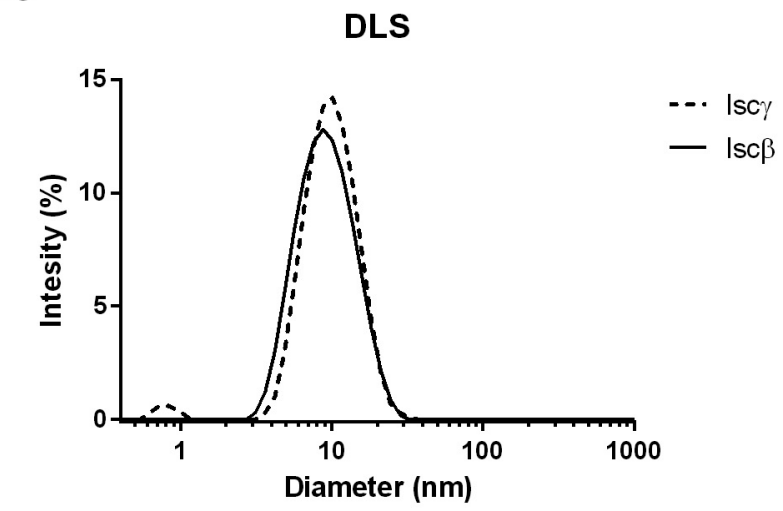

d

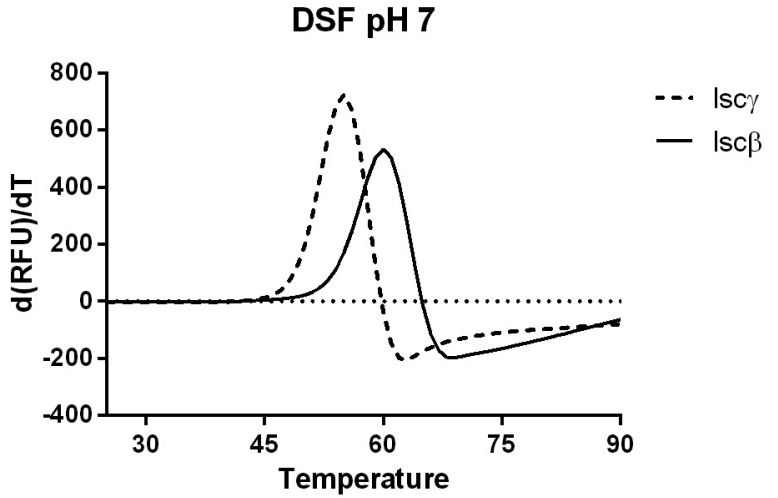

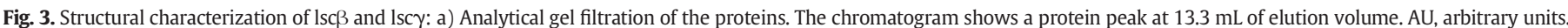

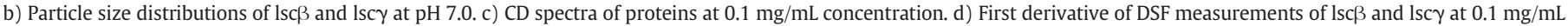
concentration using Sypro orange as environmentally sensitive dye.

than 8 (Fig. 4a). Interestingly, we found that at $\mathrm{pH} 7.0$ the activity of $\operatorname{lsc} \beta$ increase over lsc $\gamma$, reaching a hydrolysis rate twice than that of lsc $\gamma$ $\left(299.5 \pm 26.7 \mu \mathrm{g}\right.$ glucose $\mathrm{x} \mathrm{min}^{-1}$ of $1 \mathrm{sc} \beta$ respect to $170 \pm 10.6 \mathrm{mg}$ glu-

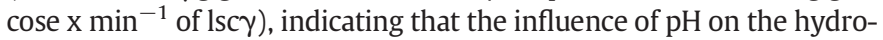
lytic activity of $\operatorname{lsc} \beta$ is considerably more pronounced respect to lsc $\gamma$.

The optimum ionic strength for enzymatic activity was detected by incubating both enzymes at $\mathrm{pH}$ 7.0, in the presence of increasing salt concentrations. Indeed, the activity of both $\operatorname{lsc} \beta$ and $1 s c \gamma$ (Fig. 4b) was negatively affected by salt concentration, even if $\operatorname{lsc} \beta$ activity decreases more sharply than that of lsc $\gamma$. This finding suggests that the activity of these enzymes is differently influenced by ionic strength [39].

Finally, the dependence of enzymes activity by temperature was measured. The hydrolysis rate of $1 \mathrm{sc} \beta$ and lsc $\gamma$ at two different $\mathrm{pH}$ values was analysed: (i) at pH 5.0, a value at which the enzymes work in a similar manner, and (ii) at pH 7.0, a condition in which the two proteins showed a different activity. Our results confirmed that at $\mathrm{pH} 5.0$ (Fig. 4c) the dependence of $1 \mathrm{sc} \beta$ and lsc $\gamma$ activity from temperature is very similar. Indeed, the activity of both enzymes progressively increases with temperature until $55^{\circ} \mathrm{C}$, and then fall quickly, suggesting that temperatures higher than $55^{\circ} \mathrm{C}$ induce denaturation of both enzymes (Fig. 4c).

Interestingly, the trends of the two proteins were completely different at pH 7.0 (Fig. 4d). In fact, meanwhile lsc $\gamma$ behaved in the same manner observed at $\mathrm{pH} 5.0$, the activity of $\mathrm{lsc} \beta$ increases rapidly passing from 4 to $15^{\circ} \mathrm{C}$ and remains constant up to $55^{\circ} \mathrm{C}$. Thus, at pH 7.0 the activity of lsc $\gamma$ is strongly influenced by the temperature, but the activity of lsc $\beta$ remains unchanged in a wide temperature range. Moreover, in all the tested conditions, both enzymes dramatically loosed the activity at $65{ }^{\circ} \mathrm{C}$, thereby undergoing to denaturation (Fig. $4 \mathrm{~d}$ ). Overall results obtained on lsc $\beta$ and lsc $\gamma$ hydrolysis rates highlight their different behaviour, and suggest that these two enzymes are differentially susceptible to environmental changes.

With the aim of further investigating the different activities of $\operatorname{lsc} \beta$ and lsc $y$ the main kinetic parameters of the enzymes were measured. It has been reported that lsc exhibit Michaelis-Menten kinetic properties for both the hydrolase and transferase activities [16], so we used this approach to calculate the $\mathrm{K}_{\mathrm{m}}$ and $\mathrm{k}_{\mathrm{cat}}$ of the enzymes. We observed that pH did not affects kinetic activity of lsc $\gamma$ (Fig. 5a); in fact this enzyme shows the same $\mathrm{K}_{\mathrm{m}}$ and $\mathrm{V}_{\max }$ values at $\mathrm{pH} 5.0$ and 7.0 (Table 1). Similarly, at pH 5.0 kinetic parameters of $1 \mathrm{sc} \beta$ are very close to that of lsc $\gamma$, even if these changes sharply moving from $\mathrm{pH} 5.0$ to $\mathrm{pH}$ 7.0, showing a lower substrate affinity but a higher $\mathrm{k}_{\text {cat }}$ value (Fig. $5 \mathrm{~b}$ and Table 1 ). Interestingly, despite these changes the specificity constant $\left(\mathrm{k}_{\mathrm{cat}} / \mathrm{K}_{\mathrm{m}}\right)$ does not change, suggesting that the impairment of affinity for substrate (sucrose) is compensated by an enhanced hydrolysis rate. This finding suggests that the shift of $\mathrm{pH}$ is related with a change in protonation status of a catalytic residue [26].

\subsection{Polymerization activity of proteins}

Time course synthesis of levan by lsc $\beta$ and lsc $\gamma$ was studied. Turbidity assay were performed on microplates in buffer at $\mathrm{pH} 5.0$ or 7.0, at 

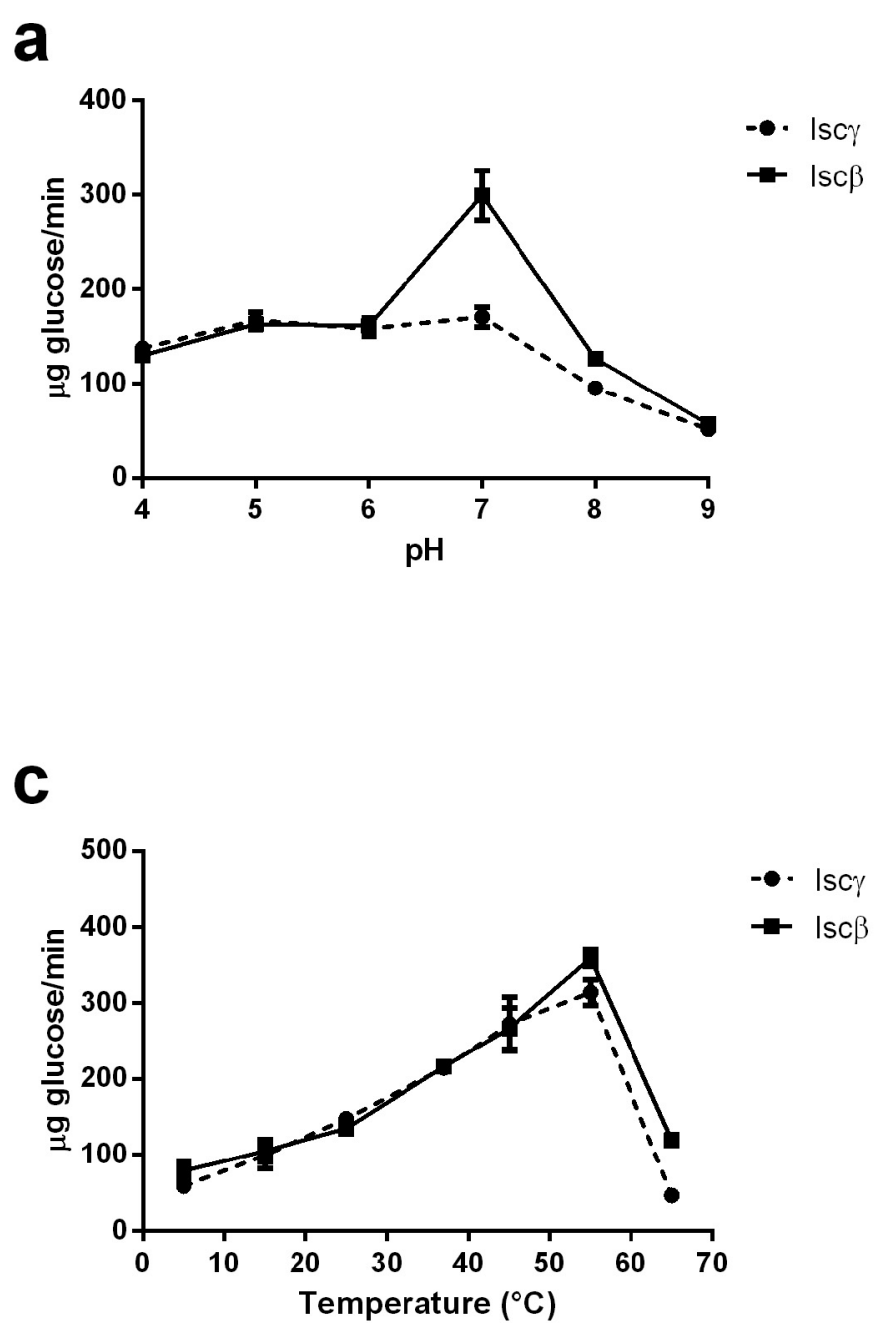

b
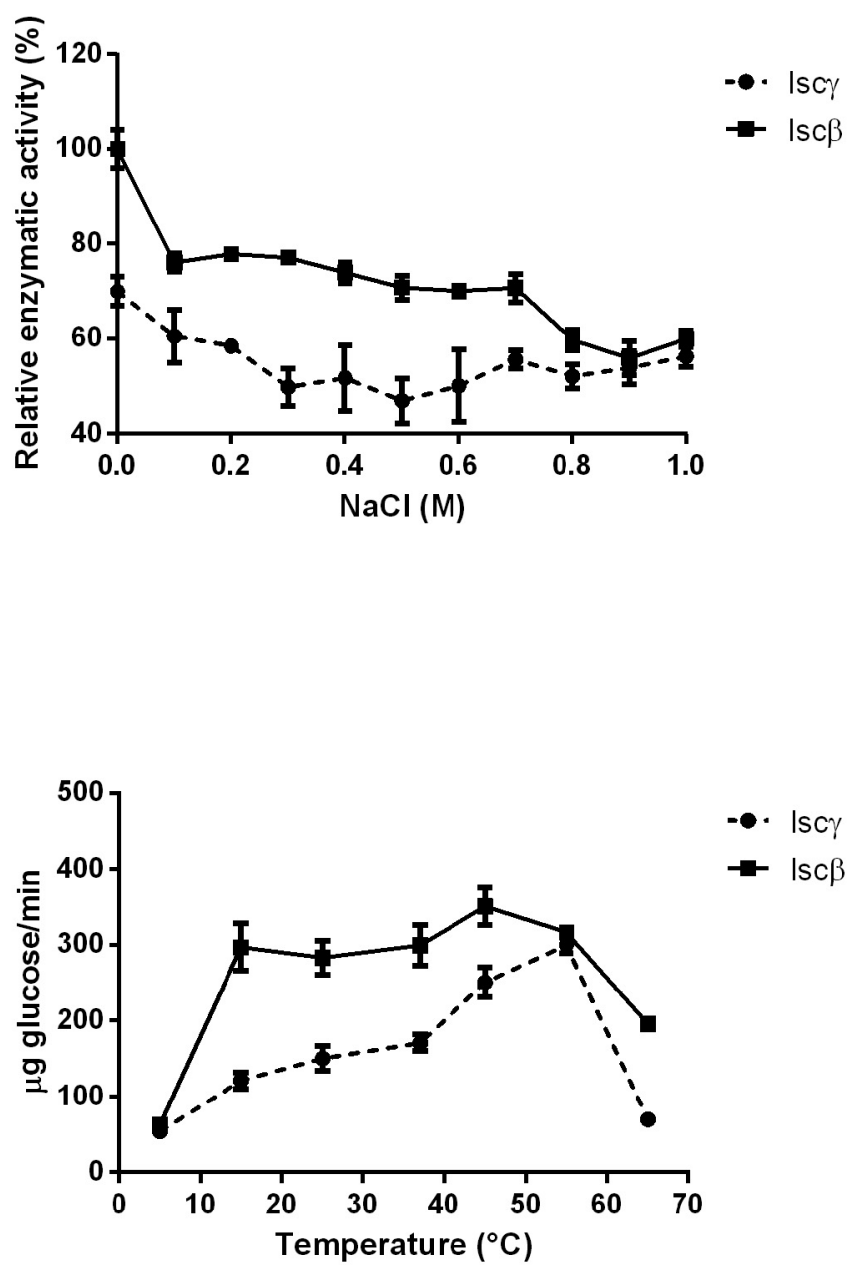

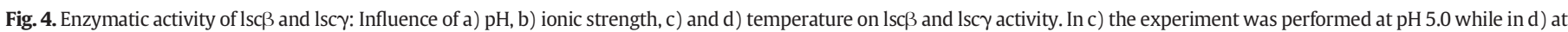
$\mathrm{pH}$ 7.0. Data are the mean and standard deviation of three different experiments.

$37{ }^{\circ} \mathrm{C}$ with $600 \mathrm{mM}$ of sucrose and equal amount of purified protein in reaction ( $10 \mu \mathrm{g}$ per $\mathrm{mL}$ of reaction mixture), being the turbidity of the solution at $400 \mathrm{~nm}$ related to levan synthesis.

Results indicated that the ability of the proteins in levan synthesis at pH 5.0 were very different (Fig. 6a). In fact, in our experimental conditions, lsc $\gamma$ showed a great increase of levan polymerization with a peak at $600 \mathrm{~min}$ and then the absorbance steadily decreases by time. The kinetics of $\operatorname{lsc} \beta$ presented a different trend showing that the increase of absorbance at $400 \mathrm{~nm}$ was very weak and strongly retarded (1600 $\mathrm{min}$ ) as compared to $1 \mathrm{sc} \gamma$ (600 $\mathrm{min}$ ). Surprisingly, at pH 7.0 the activity of the two enzymes was very similar, both producing very small amounts of levan (Fig. 6b). Based on these results it appears that in Psa3 levan formation occurs mainly at $\mathrm{pH}$ 5.0. We repeated the same experiment in the presence of $1 \mathrm{mM}$ EDTA obtaining similar results confirming that the different activity it isn't due to heavy metal ions contaminations (data not shown).

Biphasic kinetic observed with lsc $\gamma$ at pH 5.0 (Fig. 6a) suggests that the enzyme start to depolymerize levan once substrate is completely exhausted. To confirm this hypothesis, we performed a further experiment adding more sucrose when the maximum of the absorbance was reached (Fig. 6c). As expected, we observe that polymerization reaction restart and continue until a new plateau is reached. This result confirms that biphasic kinetic is due to ability of enzyme to depolymerize levan produced.

Finally, we quantified the relationship between the initial polymerization rate and sucrose concentration for both $\mathrm{lsc} \beta$ and $\mathrm{lsc} \gamma$ at $\mathrm{pH} 5.0$
(Fig. 6d). The polymerization rate of lsc $\gamma$ increased sharply in relation to sucrose concentration reaching the maximum at $100 \mathrm{mM}$ sucrose, and then steadily decreased, suggesting a strong inhibition of its activity by the substrate. Again, the behaviour of $\operatorname{lsc} \beta$ was different: the velocity of this enzyme was constant regardless of sucrose concentration and always very low as compared to lsc $\gamma$ (about 30 times) with a maximum at $200 \mathrm{mM}$ sucrose.

\section{7. $L s c \beta$ and $l s c \gamma$ showed differential expression in Psa}

Since we have demonstrated in this work either that $\operatorname{lsc} \beta$ or $\operatorname{lsc} \gamma$ are two active enzymes present in Psa3 and possess strikingly different kinetics parameters, to acquire useful information on their role in the biology of the pathogen, we have investigated their expression during the different phases of bacterial growth.

A $100 \mathrm{~mL}$ NB culture was inoculated with $100 \mu \mathrm{L}$ of $3.6 \times 10^{5} \mathrm{cfu} / \mathrm{mL}$ Psa3 solution and grown bacteria at $25^{\circ} \mathrm{C}$ for 10 days under shaking. At different time point the $l s c \beta$ and $l s c \gamma$ mRNA expression, the $\mathrm{pH}$ of culture and the bacterial total number were examined (Fig. 7). The cells growth curve obtained had the typical phases of microbial growth in culture: lag (0-4 h), exponential (4-24 h), stationary (24-48 h), and death (48-240 h) (Fig. 7a).

The initial pH of the culture was 6.9 and increased during all the experiment following the same phases of cells growth: an initial lag phase ( $0-8 \mathrm{~h})$, a drastic increase ( $8-24 \mathrm{~h})$ during which the value shifted from 6.9 to 7.8 , a stationary phase $(24-48 \mathrm{~h})$ and a final phase (48-240 h) 
a

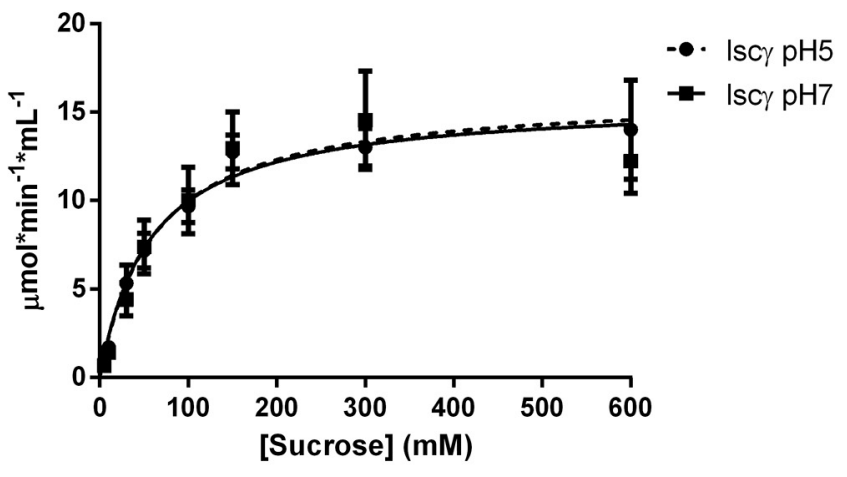

b

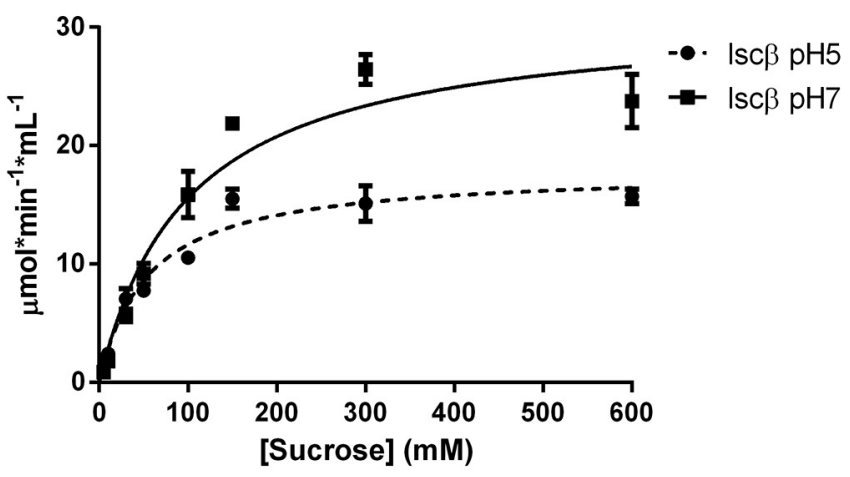

Fig. 5. Kinetic curves of lsc $\beta$ and lsc $\gamma$ at different $\mathrm{pH}$ : a) Michaelis-Menten curves of lsc $\gamma$ at pH 5.0 and 7.0. b) Michaelis-Menten curves of $\operatorname{lsc} \beta$ at pH 5.0 and 7.0. Data are the mean and standard deviation of three different experiments.

during which the pH slowly albeit constantly increased to 8.9 (240 h, end of the experiment) (Fig. 7b). Based on this evidence, we can hypothesize that during growth Psa3KL103 secretes alkaline metabolites that basify the medium, as previously reported for other Pssc members [40,41].

To evaluate the $l s c \beta$ and $l s c \gamma$ expressions during the time course pattern of the experiment, total RNA was extracted from cultivated bacteria, retro-transcribed to cDNA and analysed by qPCR method.

Results indicated that the expression level of $l s c \gamma$ did not change in a significant manner for all duration of the experiment (Fig. 7c). Differently, $l s c \beta$ was expressed at similar level of $l s c \gamma$ just after inoculation of the growth medium, but after $24 \mathrm{~h}$, the expression was increased 620 times $(0 \mathrm{~h}=0.04 \pm 0.01 \mathrm{fg} ; 24 \mathrm{~h}=24,80 \pm 3,38 \mathrm{fg})$ and finally, returned sharply to the initial level. Interestingly, the $24 \mathrm{~h}$ time point coincided with the end of the exponential phase of bacterial growth, an event that is triggered by nutrients run out, rendering plausible to speculate that this enzyme is involved in response to nutrient deficiency as well as in a mechanism of negative feedback regulation, as the rapid return to the basal level suggests. In conclusion data here presented demonstrate that, at least in vitro, the two enzymes play a different role in the physiology of Psa3.

\section{Discussion}

The ability to produce EPSs confers a selective advantage to bacteria, whether plant pathogenic or not. During the epiphytic growth on the host plant, EPSs may help to form a biofilm matrix that holds the cells together, and them to attach to surfaces, that protects the cells from dehydration and favours cell to cell communication, carbon storage and protection from antimicrobial compounds $[42,43]$. On the other hand, during the parasitic growth of a bacterial pathogen, the EPSs could render possible for the parasite to avoid or delay the activation of plant defences [44,45]. Levan production is a common feature among members of the Pssc, which is useful for discriminating its members from other fluorescent plant pathogenic Pseudomonas when grown on sucrose rich media $[1,29]$. However the biological functions of levan for this vast group of plant pathogens is poorly understood and different hypotheses are currently under investigation: it can form a "barrier" on the bacterial cell that prevents recognition and consequent active responses by the host, as well as it can be a "side product" of the active release of glucose, the major carbon source for P. syringae, from sucrose, an abundant storage sugar present in the plant apoplast [19,46]. Here, we report the description of the enzymatic activity of two novel lscs, Isc $\beta$ and lsc $\gamma$, of Psa3 the causal agent of the current pandemic of canker disease of kiwifruit. Like other P. syringae, e.g. P. syringae pv. glycinea [20] and $P$. syringae pv. tomato [47] Psa3 it possesses at least three $l s c$ genes. In particular, two are chromosome located (lsc $\alpha$ and $l s c \beta$ ) while one is plasmid borne $(l s c \gamma)$. We found that the $l s c \alpha$ sequence possess a $\mathrm{G}$ to $\mathrm{A}$ transition in position 187 that, by inducing the formation of a stop codon, probably makes the allele non-functional in this Psa lineage. Interestingly the presence of a likely non-functional $l s c A$ gene has also been described in P. syringae pv. glycinea PG 4180 due to an altered upstream region which does not seem to allow its expression [46]. Therefore, the levan production in Psa3 appears to relay on the sole $l s c \beta$ and lsc $\gamma$ alleles. Moreover the first 14 predicted amino acids residues located at the putative $\mathrm{N}$-terminus of the lsc $\gamma$ protein of Psa3, represent a unique motif among $P$. syringae levansucrases described so far [21]. Since previously characterized $1 s c C$ and $\mathrm{lscB}$ from $P$. syringae pv glycinea are strikingly similar among each other at the amino acid level differing in only five residues [48], we decided to characterize this novel enzyme also by means of comparison to the other putatively functional lsc enzyme found in Psa3 KL103, lsc $\beta$.

To the aim, lsc $\beta$ and lsc $\gamma$ gene were heterologously cloned and the recombinant proteins were expressed and purified for structural and kinetic studies. Indeed, from the structural point of view, the two Psa3 proteins presented similar CD spectra, analogue to other levansucrases, and compatible with their characteristic five-bladed $\beta$-propeller architecture [24]. Again, like several lscs [24], lsc $\beta$ and lsc $\gamma$ enzymes exist in solution in a dimeric form and are highly thermostable with a $\mathrm{T}_{\mathrm{m}}$ of $60.0{ }^{\circ} \mathrm{C}$ and $55.0{ }^{\circ} \mathrm{C}$, respectively. On the other hand, we found that they behave very differently at enzymatic level, both in terms of sucrose splitting activity and levan synthesis.

In our experimental conditions, the amount of glucose (sucrose splitting) released by $\operatorname{lsc} \beta$ was double compared to $1 s c \gamma$ at $\mathrm{pH} 7.0$, while at pH 5.0 the two enzymes showed the same activity. The

Table 1

Biochemical characteristics of sucrose catalysis for recombinant levansucrases proteins of $P$. syringae pv. actinidiae at different $\mathrm{pH}$.

\begin{tabular}{|c|c|c|c|c|}
\hline \multirow[t]{2}{*}{ Levansucrase protein } & \multirow[t]{2}{*}{$\mathrm{pH}$} & \multicolumn{3}{|l|}{ Kinetic parameters } \\
\hline & & $\mathrm{K}_{\mathrm{m}}(\mathrm{M})$ & $\mathrm{k}_{\text {cat }}\left(\min ^{-1}\right)$ & $\mathrm{k}_{\text {cat }} / \mathrm{K}_{\mathrm{m}}\left(\mathrm{M}^{-1} \mathrm{~min}^{-1}\right)$ \\
\hline $\operatorname{lsc} \beta$ & 5 & $0.0541 \pm 0.0093$ & $8,5 * 10^{3}$ & $1,6 * 10^{5}$ \\
\hline $\operatorname{lsc} \beta$ & 7 & $0.1001 \pm 0.0201$ & $1,5 * 10^{4}$ & $1,5 * 10^{5}$ \\
\hline $\operatorname{lsc} \gamma$ & 5 & $0.0604 \pm 0.0090$ & $7,3 * 10^{3}$ & $1,3 * 10^{5}$ \\
\hline $\operatorname{lsc} \gamma$ & 7 & $0.0573 \pm 0.0138$ & $7,5 * 10^{3}$ & $1,3 * 10^{5}$ \\
\hline
\end{tabular}


a

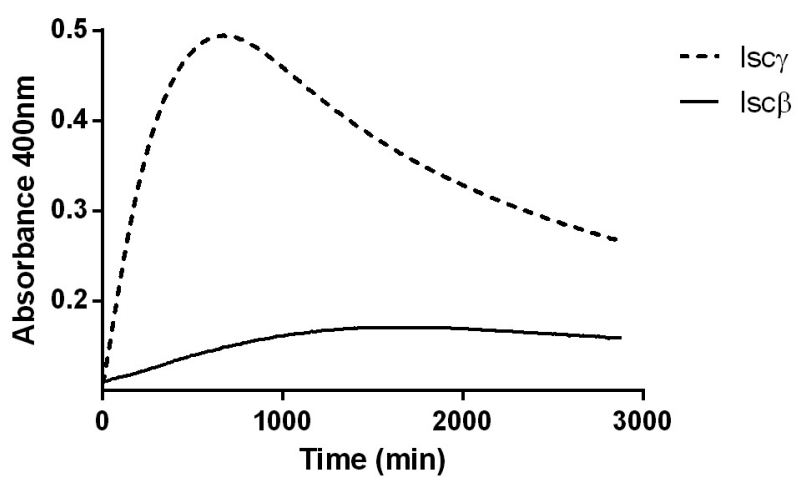

C

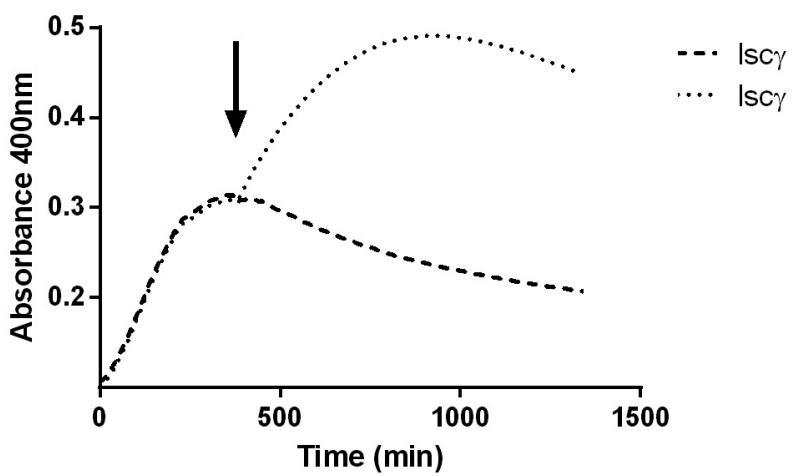

b

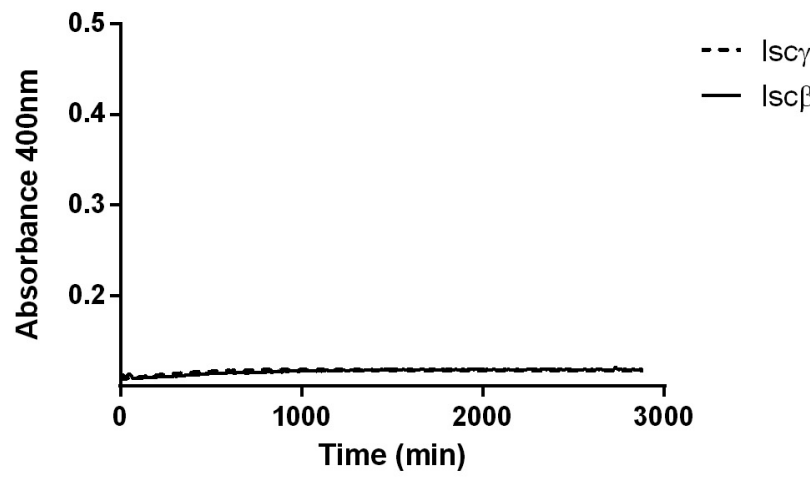

d

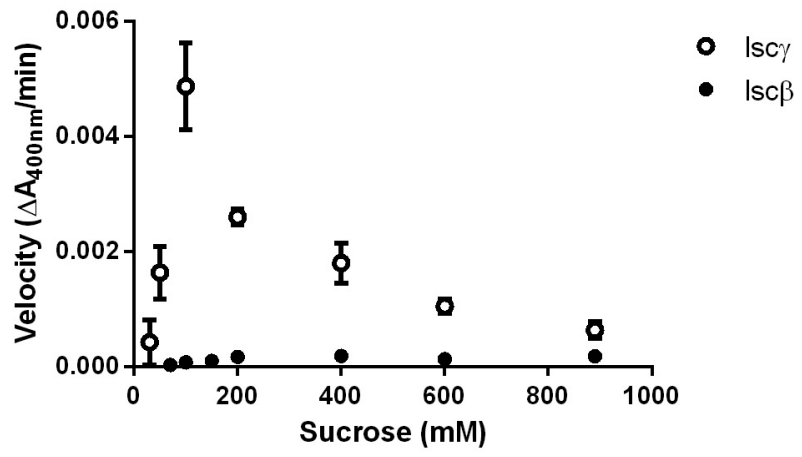

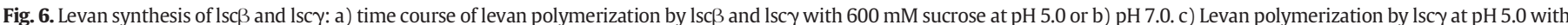

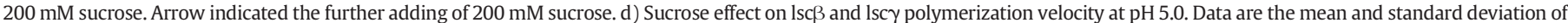
three different experiments.

differences in sucrose splitting were further corroborated by the kinetic parameter $\mathrm{K}_{\mathrm{m}}$ and $\mathrm{k}_{\text {cat }}$ of the two enzymes at these $\mathrm{pHs}$, albeit the $\mathrm{K}_{\mathrm{m}}$ and $\mathrm{k}_{\mathrm{cat}}$ that we registered are comparable to those of other characterized lscs [16,23]. Interestingly, we have found that in the case of $\operatorname{lsc} \beta$ but not in that of $1 \mathrm{sc} \gamma$, the $\mathrm{K}_{\mathrm{m}}$ e $\mathrm{k}_{\mathrm{cat}}$ changes are clearly $\mathrm{pH}$-dependent. In a similar manner, temperature and ionic strength, act differently on Psa3 $\operatorname{lsc} \beta$ and $\operatorname{lsc} \gamma$ : $\operatorname{lsc} \beta$ is little susceptible to temperature changes but more sensitive to ionic strength meanwhile for lsc $\gamma$ the opposite is true. At last also the ability of $1 s c \beta$ and lsc $\gamma$ to synthetize levan was proven to be variably affected by different reaction conditions, with lsc $y$ able to synthesize levan more quickly and in higher amounts at $\mathrm{pH} 5.0$ but not at pH 7.0 at which the two enzymes synthesize levan in the same manner albeit at lower rates and amounts. Based on the results here presented, it could be then speculated that the two lsc isoforms found in Psa3, absolve to different functions under the same environmental conditions. Already Li and Ullrich in 2001 [20], had assumed that the redundancy of $l s c$ genes in P. syringae might hint at different functions for each of the gene products, but, to the best of our knowledge, it has never been proven until now [16,21]. Remarkably, the Zymomonas mobilis lsc can exist in two different active forms depending on $\mathrm{pH}$ : at $\mathrm{pH}$ values above 7.0 the protein is a dimer with mainly sucrose hydrolysis activity, whereas at $\mathrm{pH}$ values below 6.0 , the protein assembles spontaneously to ordered filaments and filamentous networks that are biologically active and specialized in levan synthesis, suggesting that at lower $\mathrm{pH}$ values, polymer synthesis is more important for the carrier strains [49]. If this is so, it could be expected that the different environmental conditions experienced by Psa3 KL103 induce a differential expression of the two lsc genes. To the aim, we carried out a very simple experiment, culturing Psa3 KL103 on NB at a constant temperature of $28{ }^{\circ} \mathrm{C}$, that enabled us to show that, at least under in vitro conditions, Isc $\beta$ was highly expressed at the end of the exponential phase of bacterial growth, while, in the same conditions, $l s c \gamma$ was not. To prove a differential gene expression between lsc isoforms in Psa3, is of particular interest given the fact that until now this measurement had been hindered for $P$. syringae because of the nearly identical gene sequence of lsc genes $[20,21]$. Whatsoever it is possible that in our in vitro experiment we were not able to recreate the conditions in terms of $\mathrm{pH}$ for lsc $\gamma$ gene expression since we have noticed that levan synthesis by lsc $\gamma$ enzyme occurs at pH 5.0, a condition at which Psa3KL103 does not grow on artificial media. Nnevertheless under in vivo conditions the multiplication of the pathogen under this $\mathrm{pH}$ value seems plausible.

It is well known that $P$. syringae exploits stomatal openings and wounds to entry in plants apoplast which presents an acidic $\mathrm{pH}$ (from 5.0 to 5.5) and thereafter a complex sequence of events, mediated by the infection process, activates a $\mathrm{K}^{+} / \mathrm{H}^{+}$plant-borne efflux and influx, which increases the apoplastic $\mathrm{pH}$ to 7.5 [46]. Indeed Atkinson in 1987 [50] demonstrated that $P$. syringae pv. syringae multiplication in Phaseolus vulgaris is correlated with the increasing $\mathrm{pH}$ of host 
a

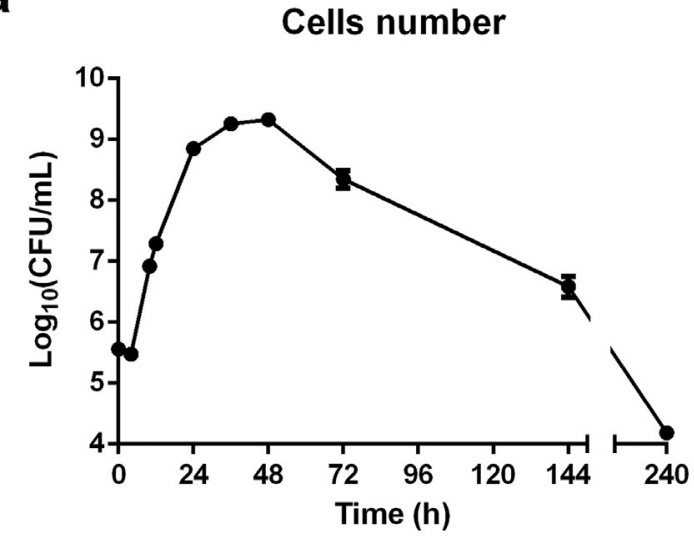

b

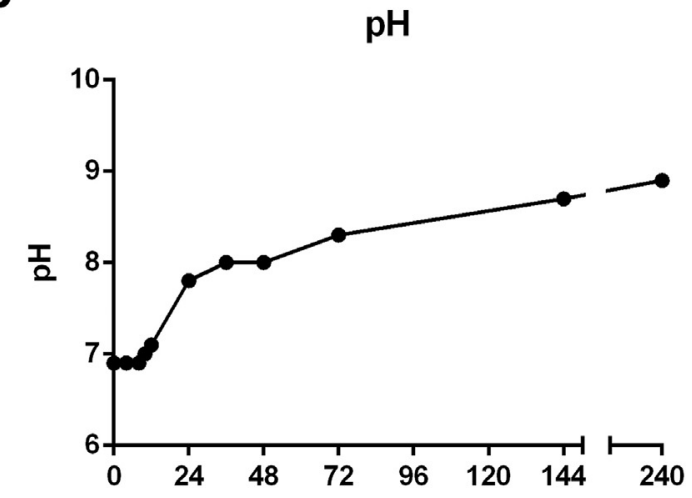

C

\section{Enzymes expression}

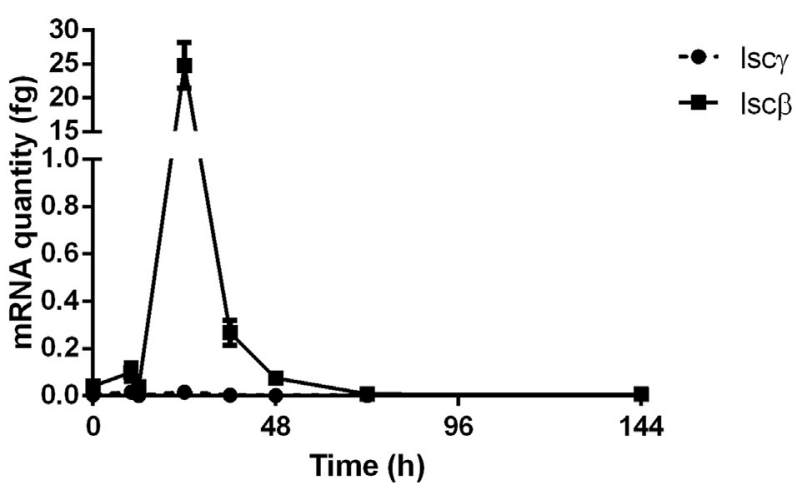

Fig. 7. $l s c \beta$ and $l s c \gamma$ gene expressions: a) Quantifications of Psa3 cells number during bacterial growth. b) $\mathrm{pH}$ values measured during bacterial growth. c) Absolute quantification of $l s c \beta$ and $l s c \gamma$ mRNA in Psa3 during bacterial growth. Data are the mean and standard deviation of three different experiments.

intercellular fluid resulting from the $\mathrm{K}^{+} / \mathrm{H}^{+}$exchange. Taking into account that the $150 \mathrm{mM}$ sucrose concentration used in our experiments is the sucrose quantity in the guard cells apoplast under photosynthetic conditions [51] and that stomata are a common port of entry for Psa $[6,52]$, it becomes easy to speculate that the two active isoforms of Psa3 lscs here characterized could have different functions during the infection process of Actinidia spp. Since one of the first line of plant defence is to remove sucrose availability for pathogens [53], then lsc $\gamma$ could facilitate pathogen early stages of process (biotrophic phase), when the quick polymerization of levan would allow the bacterium to mask and protect itself providing at the same time a form of nutrient storage [18], at a higher $\mathrm{pH}$ value, lsc $\beta$ would accelerate pathogen multiplication (necrotrophic phase) by producing large quantities of glucose for metabolism [54].

Further investigations are compelling to elucidate the role of the two enzymes in relation to $\mathrm{pH}$ changes, as well as in relation to temperature, a factor that had been recently proven to affected leaf colonization process of Actinidia spp. by Psa3 [55]. In fact, our data also indicated that the hydrolytic activity of $\operatorname{lsc} \beta$ was always near to its maximum at all temperatures tested while lsc $\gamma$ did not.

Apart from the phytopathological considerations, lsc exhibit great potential in food and pharmaceutical industries, in fact, levan has several applications such as nondigestible soluble dietary fiber and prebiotic compound or as drug showing antiobesity, antioxidant and antitumor effect [56]. The results obtained in the present study showed that lsc $\gamma$ is a highly stable levan producing protein at pH 5.0 and represent a good candidate for industrial application. In addition, future experiment highlighting the structural differences between lsc $\beta$ and lsc $\gamma$ could reveal the key aminoacids that promote polymerization or hydrolysis. It has not escaped our notice that hydrolysis and transfructosylation reactions of lsc could be catalysed on different parts of the protein. Lsc $\beta$ and lsc $\gamma$ enzymes share a $94.6 \%$ of identity at amino acid level. Since 14 out of 23 different positions are located at the $\mathrm{N}$-terminal region, it will be of sure interest to investigate whether or not this region is responsible for the observed different behaviour in sucrose/polymer binding between the two enzymes, under different $\mathrm{pH}$ conditions. At last, also the comparison of the $\mathrm{k}_{\text {cat }}$ and $\mathrm{K}_{\mathrm{m}}$ supports the existence of two different enzymes in Psa3, whose activity, under the same conditions, markedly differs both in terms of affinity for the substrate $\left(\mathrm{K}_{\mathrm{m}}\right)$ and of catalytic activity $\left(\mathrm{k}_{\text {cat }}\right)$.

To the best of our knowledge, this is the first report with experimental evidence highlighting the possible different localization of the hydrolysis and transfructosylation reactions in lsc which till now were only supposed by molecular modelling [57].

Supplementary data to this article can be found online at https://doi. org/10.1016/j.ijbiomac.2021.02.189.

\section{Funding}

This study was supported by the University of Florence (Fondi di Ateneo 2019 e 2020) and the Phytosanitary Service of the Tuscany Region.

\section{CRediT authorship contribution statement}

Simone Luti: Conceptualization; Data curation; Investigation; Writing - original draft. Sara Campigli: Investigation; Methodology; Data curation; Writing, review \& editing. Francesco Ranaldi: Methodology; Formal analysis; Writing, review \& editing. Paolo Paoli: Validation; Visualization; Writing, review \& editing. Luigia Pazzagli: Funding acquisition; Resources; Writing, review \& editing. Guido Marchi: Conceptualization; Resources; Funding acquisition; Supervision; Writing, review \& editing.

\section{Acknowledgements}

Dr. Simone Luti and Dr. Sara Campigli were financed by a grant from the Phytosanitary Service of the Tuscany Region and the University of Florence (Italy). We are grateful to Dr. Costanza Cicchi for her contribution in sucrose hydrolysis experiments during her bachelor's degree Thesis and Dr. Domenico Rizzo for feedback on the manuscript.

The authors declare no conflict of interest.

\section{References}

[1] L. Gardan, C. Bollet, M. Abu Ghorrah, F. Grimont, P.A.D. Grimont, DNA relatedness among the pathovar strains of Pseudomonas syringae subsp. savastanoi Janse (1982) and proposal of Pseudomonas savastanoi sp. nov, Int. J. Syst. Bacteriol. 42 (1992) 606-612, https://doi.org/10.1099/00207713-42-4-606. 
[2] T. Fujikawa, H. Sawada, Genome analysis of the kiwifruit canker pathogen Pseudomonas syringae pv. actinidiae biovar 5, Sci. Rep. 6 (2016), 21399, https://doi.org/ 10.1038/srep21399.

[3] J.R. Chapman, R.K. Taylor, B.S. Weir, M.K. Romberg, J.L. Vanneste, J. Luck, B.J.R. Alexander, Phylogenetic relationships among global populations of Pseudomonas syringae pv. actinidiae, Phytopathology® 102 (2012) 1034-1044, https://doi.org/ 10.1094/PHYTO-03-12-0064-R

[4] H. Sawada, T. Miyoshi, Y. Ide, Novel MLSA group (Psa5) of Pseudomonas syringae pv. actinidiae causing bacterial canker of kiwifruit (Actinidia chinensis) in Japan, Japanese Journal of Phytopathology 80 (2014) 171-184, https://doi.org/10.3186/ jjphytopath.80.171.

[5] A. Cunty, F. Poliakoff, C. Rivoal, S. Cesbron, M. Fischer-Le Saux, C. Lemaire, M.A. Jacques, C. Manceau, J.L. Vanneste, Characterization of Pseudomonas syringae pv. actinidiae (Psa) isolated from France and assignment of Psa biovar 4 to a de novo pathovar: Pseudomonas syringae pv. actinidifoliorum pv. nov, Plant Pathol. 64 (2015) 582-596, https://doi.org/10.1111/ppa.12297.

[6] J.L. Vanneste, The scientific, economic, and social impacts of the New Zealand outbreak of bacterial canker of kiwifruit (Pseudomonas syringae pv. actinidiae), Annu. Rev. Phytopathol. 55 (2017) 377-399, https://doi.org/10.1146/annurevphyto-080516-035530.

7] H.C. Mccann, E.H.A. Rikkerink, F. Bertels, M. Fiers, A. Lu, J. Rees-George, M.T. Andersen, A.P. Gleave, B. Haubold, M.W. Wohlers, D.S. Guttman, P.W. Wang, C. Straub, J. Vanneste, P.B. Rainey, M.D. Templeton, Genomic analysis of the kiwifruit pathogen Pseudomonas syringae pv. actinidiae provides insight into the origins of an emergent plant disease, PLoS Pathog. 9 (2013), e1003503, https://doi.org/10. 1371/journal.ppat.1003503.

[8] H. Sawada, S. Shimizu, T. Miyoshi, T. Shinozaki, S. Kusumoto, M. Noguchi, T. Naridomi, K. Kikuhara, M. Kansako, T. Fujikawa, R. Nakaune, Characterization of biovar 3 strains of Pseudomonas syringae pv. Actinidiae isolated in Japan, Japanese Journal of Phytopathology 81 (2015) 111-126, https://doi.org/10.3186/ jjphytopath.81.111.

[9] P. Petrova, K. Petrov, Lactic acid fermentation of cereals and pseudocereals: ancient nutritional biotechnologies with modern applications, Nutrients 12 (2020) 1118, https://doi.org/10.3390/nu12041118.

[10] A. Lovato, A. Pignatti, N. Vitulo, E. Vandelle, A. Polverari, Inhibition of virulencerelated traits in Pseudomonas syringae pv. actinidiae by gunpowder green tea extracts, Front. Microbiol. 10 (2019)https://doi.org/10.3389/fmicb.2019.02362.

[11] P.A. Mcatee, L. Brian, B. Curran, O. van der Linden, N.J. Nieuwenhuizen, X. Chen, R.A. Henry-Kirk, E.A. Stroud, S. Nardozza, J. Jayaraman, E.H.A. Rikkerink, C.G. Print, A.C. Allan, M.D. Templeton, Re-programming of Pseudomonas syringae pv. actinidiae gene expression during early stages of infection of kiwifruit, BMC Genomics 19 (2018), 822, https://doi.org/10.1186/s12864-018-5197-5.

[12] S.P. Kidambi, G.W. Sundin, D.A. Palmer, A.M. Chakrabarty, C.L. Bender, Copper as a signal for alginate synthesis in Pseudomonas syringae pv. syringae, Appl. Environ. Microbiol. 61 (1995) 2172-2179, https://doi.org/10.1128/AEM.61.6.2172-2179. 1995.

[13] J. Yu, A. Penaloza-Vazquez, A.M. Chakrabarty, C.L. Bender, Involvement of the exopolysaccharide alginate in the virulence and epiphytic fitness of Pseudomonas syringae pv. syringae, Mol. Microbiol. 33 (1999) 712-720, https://doi.org/10.1046/ j.1365-2958.1999.01516.x.

[14] R.C. Keith, L.M.W. Keith, G. Hernández-Guzmán, S.R. Uppalapati, C.L. Bender, Alginate gene expression by Pseudomonas syringae pv. tomato DC3000 in host and non-host plants, Microbiology 149 (2003) 1127-1138, https://doi.org/10.1099/ mic.0.26109-0.

[15] T.C. Helmann, A.M. Deutschbauer, S.E. Lindow, Genome-wide identification of Pseudomonas syringae genes required for fitness during colonization of the leaf surface and apoplast, Proc. Natl. Acad. Sci. 116 (2019) 18900-18910, https://doi.org/10. 1073/pnas.1908858116.

[16] E.T. Öner, L. Hernández, J. Combie, Review of Levan polysaccharide: from a century of past experiences to future prospects, Biotechnol. Adv. 34 (2016) 827-844, https://doi.org/10.1016/j.biotechadv.2016.05.002.

[17] P. Bogino, M. Oliva, F. Sorroche, W. Giordano, The role of bacterial biofilms and surface components in plant-bacterial associations, Int. J. Mol. Sci. 14 (2013) 15838-15859, https://doi.org/10.3390/ijms140815838.

[18] H. Laue, A. Schenk, H. Li, L. Lambertsen, T.R. Neu, S. Molin, M.S. Ullrich, Contribution of alginate and levan production to biofilm formation by Pseudomonas syringae, Microbiology 152 (2006) 2909-2918, https://doi.org/10.1099/mic.0.28875-0.

[19] S. Kasapis, E.R. Morris, M. Gross, K. Rudolph, Solution properties of levan polysaccharide from Pseudomonas syringae pv. phaseolicola, and its possible primary role as a blocker of recognition during pathogenesis, Carbohydr. Polym. 23 (1994) 55-64, https://doi.org/10.1016/0144-8617(94)90090-6.

[20] H. Li, M.S. Ullrich, Characterization and mutational analysis of three allelic lsc genes encoding levansucrase in Pseudomonas syringae, J. Bacteriol. 183 (2001) 3282-3292, https://doi.org/10.1128/JB.183.11.3282-3292.2001.

[21] A. Srivastava, N. Al-Karablieh, S. Khandekar, A. Sharmin, H. Weingart, M.S. Ullrich, Genomic distribution and divergence of levansucrase-coding genes in Pseudomonas syringae, Genes 3 (2012) 115-137, https://doi.org/10.3390/genes3010115.

[22] T. Visnapuu, K. Mardo, C. Mosoarca, A.D. Zamfir, A. Vigants, T. Alamäe, Levansucrases from Pseudomonas syringae pv. tomato and P. chlororaphis subsp. aurantiaca: substrate specificity, polymerizing properties and usage of different acceptors for fructosylation, J. Biotechnol. 155 (2011) 338-349, https://doi.org/10.1016/j.jbiotec. 2011.07.026.

[23] T. Visnapuu, K. Mardo, T. Alamäe, Levansucrases of a Pseudomonas syringae pathovar as catalysts for the synthesis of potentially prebiotic oligo- and polysaccharides, New Biotechnol. 32 (2015) 597-605, https://doi.org/10.1016/j.nbt.2015. 01.009 .
[24] M.E. Ortiz-Soto, J.R. Porras-Domínguez, J. Seibel, A. López-Munguía, A close look at the structural features and reaction conditions that modulate the synthesis of low and high molecular weight fructans by levansucrases, Carbohydr. Polym. 219 (2019) 130-142, https://doi.org/10.1016/j.carbpol.2019.05.014.

[25] K. Mardo, T. Visnapuu, H. Vija, T. Elmi, T. Alamäe, Mutational analysis of conserved regions harboring catalytic triad residues of the levansucrase protein encoded by the lsc-3 gene ( Isc3 ) of Pseudomonas syringae pv. tomato DC3000, Biotechnol. Appl. Biochem. 61 (2014) 11-22, https://doi.org/10.1002/bab.1129.

[26] G. Rabbani, E. Ahmad, N. Zaidi, R.H. Khan, pH-dependent conformational transitions in conalbumin (ovotransferrin), a metalloproteinase from hen egg white, Cell Biochem. Biophys. 61 (2011) 551-560, https://doi.org/10.1007/s12013-011-9237-x.

[27] W. Xu, D. Ni, W. Zhang, C. Guang, T. Zhang, W. Mu, Recent advances in levansucrase and inulosucrase: evolution, characteristics, and application, Crit. Rev. Food Sci. Nutr. 59 (2019) 3630-3647, https://doi.org/10.1080/10408398.2018.1506421.

[28] S.K. Mohan, An improved agar plating assay for detecting Pseudomonas syringae pv. syringae and P. s. pv. Phaseolicola in contaminated bean seed, Phytopathology 77 (1987) 1390, https://doi.org/10.1094/Phyto-77-1390.

[29] R.A. Lelliott, E. Billing, A.C. Hayward, A determinative scheme for the fluorescent plant pathogenic pseudomonads, J. Appl. Bacteriol. 29 (1966) 470-489, https:// doi.org/10.1111/j.1365-2672.1966.tb03499.x.

[30] S. Kumar, G. Stecher, M. Li, C. Knyaz, K. Tamura, MEGA X: molecular evolutionary genetics analysis across computing platforms, Mol. Biol. Evol. 35 (2018) 1547-1549, https://doi.org/10.1093/molbev/msy096.

[31] M.V. Vega, A. Nigro, S. Luti, C. Capitini, G. Fani, L. Gonnelli, F. Boscaro, F. Chiti, Isolation and characterization of soluble human full-length TDP-43 associated with neurodegeneration, FASEB J. 33 (2019) 10780-10793, https://doi.org/10.1096/fj. 201900474R.

[32] G. Rabbani, E. Ahmad, M.V. Khan, M.T. Ashraf, R. Bhat, R.H. Khan, Impact of structural stability of cold adapted Candida antarctica lipase B (CaLB): in relation to $\mathrm{pH}$, chemical and thermal denaturation, RSC Adv. 5 (2015) 20115-20131, https://doi.org/10. 1039/C4RA17093H

[33] A. El Khatib, Practical biochemistry principles and techniques approach, Progress in Chemical and Biochemical Research 3 (2020) 180-193.

[34] C. Gonçalves, R.M. Rodriguez-Jasso, N. Gomes, J.A. Teixeira, I. Belo, Adaptation of dinitrosalicylic acid method to microtiter plates, Anal. Methods 2 (2010) 2046, https://doi.org/10.1039/c0ay00525h.

[35] H.C. Ball, R.K. Holmes, R.L. Londraville, J.G.M. Thewissen, R.J. Duff, Leptin in whales: validation and measurement of mRNA expression by absolute quantitative real-time PCR, PLoS One 8 (2013), e54277, https://doi.org/10.1371/journal.pone.0054277.

[36] R.T.M. Poulter, J. Ho, T. Handley, G. Taiaroa, M.I. Butler, Comparison between complete genomes of an isolate of Pseudomonas syringae pv. actinidiae from Japan and a New Zealand isolate of the pandemic lineage, Sci. Rep. 8 (2018), 10915 , https://doi.org/10.1038/s41598-018-29261-5.

[37] B. Caroline, M. Goncalves, C. Baldo, M. Antonia, P. Colabone, Levan And Levansucrase-A Mini Review, Int. J. Sci. Technol. Res. 4 (2015) 100-104.

[38] A. Mukherjee, S. Banerjee, R. Gachhui, Investigation of conformational changes of levansucrase isolated from Acetobacter nitrogenifigens strain RG1 by mercuric and cadmium ion, Int. J. Biol. Macromol. 120 (2018) 189-194, https://doi.org/10. 1016/j.ijbiomac.2018.08.083.

[39] G. Rabbani, I. Choi, Roles of osmolytes in protein folding and aggregation in cells and their biotechnological applications, Int. J. Biol. Macromol. 109 (2018) 483-491, https://doi.org/10.1016/j.ijbiomac.2017.12.100.

[40] M.A.P. Manzoor, S.R. Duwal, M. Mujeeburahiman, P.-D. Rekha, Vitamin C inhibits crystallization of struvite from artificial urine in the presence of Pseudomonas aeruginosa, International Braz j Urol 44 (2018) 1234-1242, https://doi.org/10. 1590/s1677-5538.ibju.2017.0656.

[41] D.R. Kurnia, W. Mangunwardoyo, H. Ambarsari, Biodegradation of used lubricant oil hydrocarbons using Bacillus subtilis InaCC B289 and Pseudomonas aeruginosa InaCC B290 in single or mixed cultures, 2018 070007, https://doi.org/10.1063/1.5062805.

[42] S. Tsuneda, H. Aikawa, H. Hayashi, A. Yuasa, A. Hirata, Extracellular polymeric substances responsible for bacterial adhesion onto solid surface, FEMS Microbiol. Lett. 223 (2003) 287-292, https://doi.org/10.1016/S0378-1097(03)00399-9.

[43] O.Y.A. Costa, J.M. Raaijmakers, E.E. Kuramae, Microbial extracellular polymeric substances: ecological function and impact on soil aggregation, Front. Microbiol. 9 (2018)https://doi.org/10.3389/fmicb.2018.01636.

[44] Z. Király, H.M. El-Zahaby, Z. Klement, Role of extracellular polysaccharide (EPS) slime of plant pathogenic bacteria in protecting cells to reactive oxygen species, J. Phytopathol. 145 (1997) 59-68, https://doi.org/10.1111/j.1439-0434.1997.tb00365.x.

[45] M.C. de Pinto, P. Lavermicocca, A. Evidente, M.M. Corsaro, S. Lazzaroni, L. De Gara, Exopolysaccharides produced by plant pathogenic bacteria affect ascorbate metabolism in Nicotiana tabacum, Plant Cell Physiol. 44 (2003) 803-810, https://doi.org/ 10.1093/pcp/pcg105.

[46] A. Mehmood, K. Abdallah, S. Khandekar, D. Zhurina, A. Srivastava, N. Al-Karablieh, G. Alfaro-Espinoza, D. Pletzer, M.S. Ullrich, Expression of extra-cellular levansucrase in Pseudomonas syringae is controlled by the in planta fitness-promoting metabolic repressor HexR, BMC Microbiol. 15 (2015) 48, https://doi.org/10.1186/s12866015-0349-0.

[47] T. Visnapuu, A. Mäe, T. Alamäe, Hansenula polymorpha maltase gene promoter with sigma 70-like elements is feasible for Escherichia coli-based biotechnological applications: expression of three genomic levansucrase genes of Pseudomonas syringae pv. tomato, Process Biochem. 43 (2008) 414-422, https://doi.org/10.1016/j. procbio.2008.01.002.

[48] H. Li, A. Schenk, A. Srivastava, D. Zhurina, M.S. Ullrich, Thermo-responsive expression and differential secretion of the extracellular enzyme levansucrase in the plant pathogenic bacterium Pseudomonas syringae pv. glycinea, FEMS Microbiol. Lett. 265 (2006) 178-185, https://doi.org/10.1111/j.1574-6968.2006.00486.x. 
[49] D. Goldman, N. Lavid, A. Schwartz, G. Shoham, D. Danino, Y. Shoham, Two active forms of Zymomonas mobilis levansucrase, J. Biol. Chem. 283 (2008) 32209-32217, https://doi.org/10.1074/jbc.M805985200.

[50] M.M. Atkinson, Association of host plasma membrane $\mathrm{K}+/ \mathrm{H}+$ exchange with multiplication of Pseudomonas syringae pv. syringae in Phaseolus vulgaris, Phytopathology 77 (1987) 1273, https://doi.org/10.1094/Phyto-77-1273.

[51] Y. Kang, W.H. Outlaw, P.C. Andersen, G.B. Fiore, Guard-cell apoplastic sucrose concentration? A link between leaf photosynthesis and stomatal aperture size in the apoplastic phloem loader Vicia faba L, Plant Cell Environ. 30 (2007) 551-558, https://doi.org/10.1111/j.1365-3040.2007.01635.x.

[52] I. Donati, A. Cellini, D. Sangiorgio, J.L. Vanneste, M. Scortichini, G.M. Balestra, F. Spinelli, Pseudomonas syringae pv. actinidiae: ecology, infection dynamics and disease epidemiology, Microb. Ecol. 80 (2020) 81-102, https://doi.org/10.1007/ s00248-019-01459-8.

[53] L-O Chen, X-O Qu, B.-H. Hou, D. Sosso, S. Osorio, A.R. Fernie, W.B. Frommer, Sucrose efflux mediated by SWEET proteins as a key step for phloem transport, Science 335 (2012) 207-211, https://doi.org/10.1126/science.1213351.
[54] M. Petriccione, A.M. Salzano, I. Di Cecco, A. Scaloni, M. Scortichini, Proteomic analysis of the Actinidia deliciosa leaf apoplast during biotrophic colonization by Pseudomonas syringae pv. actinidiae, J. Proteome 101 (2014) 43-62, https://doi.org/10.1016/j. jprot.2014.01.030.

[55] X. Gao, Q. Huang, Z. Zhao, Q. Han, X. Ke, H. Qin, L. Huang, Studies on the infection, colonization, and movement of Pseudomonas syringae pv. actinidiae in kiwifruit tissues using a GFPuv-labeled strain, PLoS One 11 (2016), e0151169, https://doi.org/ 10.1371/journal.pone.0151169.

[56] W. Li, S. Yu, T. Zhang, B. Jiang, W. Mu, Recent novel applications of levansucrases, Appl. Microbiol. Biotechnol. 99 (2015) 6959-6969, https://doi.org/10.1007 s00253-015-6797-5.

[57] B. Bakar, B. Kaplan-Türköz, Structural modelling and structure-function analysis of Zymomonas mobilis levansucrase, Süleyman Demirel Üniversitesi Fen Bilimleri Enstitüsü Dergisi 21 (2017) 279, https://doi.org/10.19113/sdufbed.81065. 